\title{
Analysis of the climatic mechanisms contributing to the summertime transport of lower atmospheric ozone across metropolitan Phoenix, Arizona, USA
}

\author{
Andrew W. Ellis ${ }^{1, *}$, Mark L. Hildebrandt' ${ }^{2}$, Wendy M. Thomas ${ }^{1}$, H. J. S. Fernando ${ }^{3}$ \\ ${ }^{1}$ Department of G eography and ${ }^{3}$ Department of Mechanical and Aerospace Engineering, A rizona State University, \\ Tempe, A rizona 85287, USA \\ ${ }^{2}$ Department of G eography, Southern Illinois University-Edwardsville, Edwardsville, Illinois 62026, USA
}

\begin{abstract}
High concentrations of lower atmospheric ozone can adversely affect the health of humans, plants, and animals. Over the past decade, unhealthy levels of ozone across the Phoenix, Arizona (USA) urban area have been a focus of attention for the United States Environmental Protection Agency (EPA) and local government agencies. As ozone concentrations exceeding the standard set forth by the EPA occur in a preferred location within the Phoenix metropolitan area (eastern suburb of Mesa), it has become important to gain an understanding of the mechanisms that transport ozone within Phoenix and its suburbs. The objective of the study that is presented here was to examine the climatic factors that contributed to the spatial distribution of lower atmospheric ozone across the eastern portion of the Phoenix metropolitan area in mid-to-late summer 1998. M icroclimatic and synopticscale atmospheric contributors were linked to the mesoscale transport of ozone. Forty-three study days were stratified into 3 categories: high ozone days (exceeded the EPA standard), moderate ozone days (approached the EPA standard), and low ozone days. Eleven days of high ozone were differentiated from the days of the remaining 2 categories by an atmosphere containing less water vapor, and therefore a greater surface receipt of insolation. This is not surprising given the fact that ozone production is a photochemical process. However, the movement of the lower atmospheric ozone is also an important issue. The results of the study suggest that the drier atmosphere and resultant high insolation at the surface were associated with a proximal area of high pressure aloft. Taken together, the result was warmer ground surface and overlying air temperatures, light winds, an apparent lack of turbulent lower atmospheric mixing, and light southwesterly winds at $850 \mathrm{mb}$ that advected little moisture into the area. Associated with the light synoptic flow and warm surface condition on days of high ozone was a wind regime that appears to be the product of a mesoscale thermodynamic circulation. The daytime flow on high ozone days became directed upslope toward the higher elevations of the eastern Phoenix Valley. Embedded within the flow was a plume of high ozone concentrations that extended from an urban area of high ground traffic eastward into the eastern suburb of M esa. Conversely, moderate and low ozone days were associated with an eastward displacement of high pressure aloft, greater advection of lowlevel moisture from the south and southeast, smaller insolation receipt, less surface heating, and a much less organized movement of lower atmospheric ozone than on high ozone days.
\end{abstract}

KEY WORDS: Ozone transport · Thermal circulation · Scale interactions · Phoenix, AZ

\section{INTRODUCTION}

The combustion of petroleum and oil by ground vehicles and aircraft, along with industrial by-products, often produce significant amounts of atmospheric

*E-mail: andrew.w.ellis@asu.edu pollution across large urban centers. As with the classic example of Los Angeles, California (USA), the transport of pollution away from some urban areas is restricted by the surrounding topography. When a weak background synoptic circulation combines with valley air temperature inversions and the surrounding orographic blockade, the result is often the lack of a 

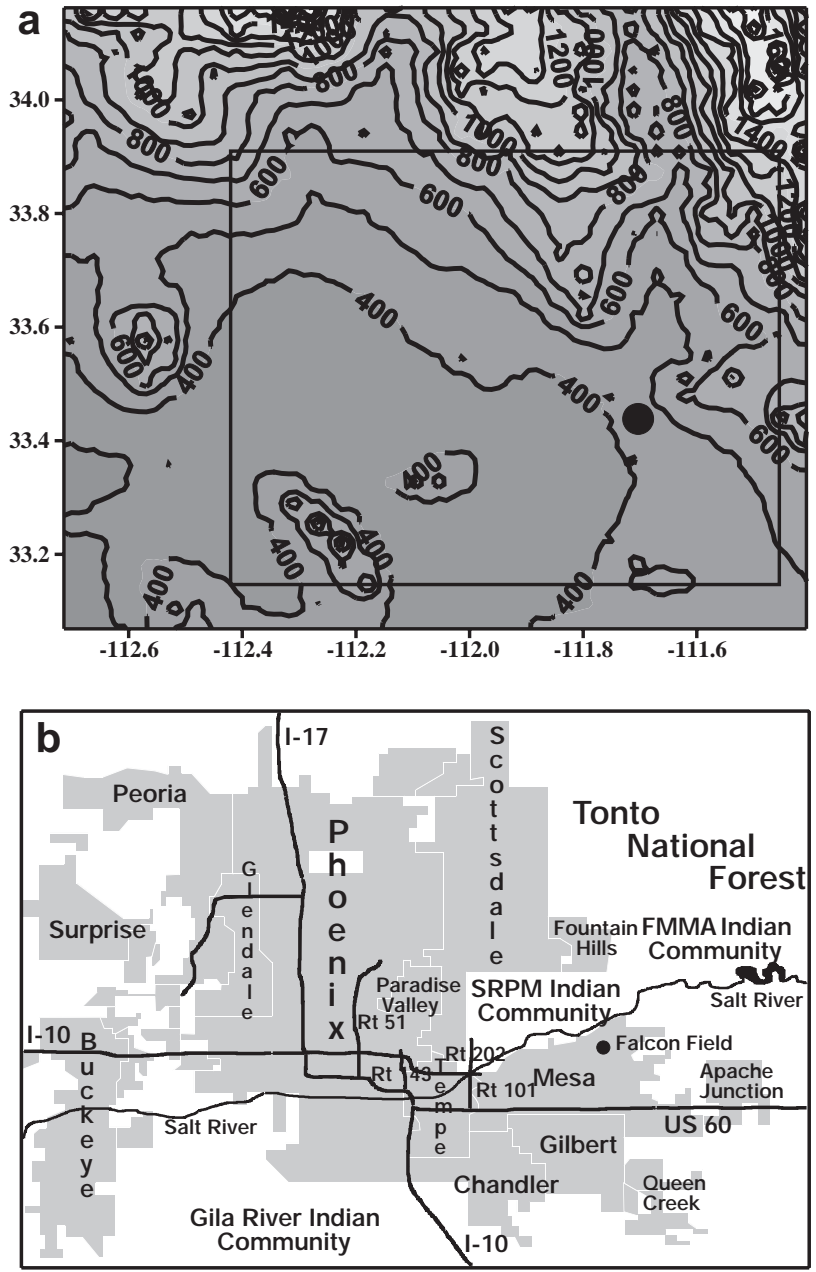

Fig. 1. The elevation (a) that is associated with the Phoenix Valley, Arizona, within which is located the Phoenix metropolitan area (b). Elevation values are in meters. The location of the metropolitan area (b) is indicated on the elevation map (a). The location $(\bullet)$ of the Falcon Field Regional Airport within Mesa is located on each map

significant transport of lower atmospheric pollutants away from the urban center (Berman et al. 1995, Lu \& Turco 1995).

Phoenix, Arizona (USA), is similar to Los Angeles in that the metropolitan area is rather densely populated, is experiencing a rapid population growth, and is situated in an arid environment of complex topography (Gammon et al. 1981), whereby the urban center is nearly surrounded by significantly higher terrain (Fig. 1a). Due to characteristic terrain features and a consistent lack of a strong synoptic background circulation, the Phoenix urban area is thought to be subject to a year-round predominant thermodynamically driven mesoscale atmospheric circulation (Sellers \& Hill 1974, Davis \& Gay 1993). Despite the low wind speeds that characterize the Phoenix area (Sellers \& Hill 1974), it is likely that the mesoscale circulation is capable of transporting atmospheric contaminants. In terms of human health, one of the more dangerous pollutants circulated about the Phoenix Valley is ozone.

Ozone is produced naturally through a photochemical process in which ultraviolet radiation disassociates natural nitrogen dioxide $\left(\mathrm{NO}_{2}\right)$ into nitrogen oxide (NO) and atomic oxygen (O). A tomic oxygen can then combine with molecular oxygen $\left(\mathrm{O}_{2}\right)$ to produce ozone $\left(\mathrm{O}_{3}\right)$. Ozone also reacts with artificial NO to produce $\mathrm{NO}_{2}$, which goes into the photochemical cycle to form a positive feedback loop. Likewise, the anthropogenic contribution of $\mathrm{NO}_{2}$ through the high-temperature combustion of fuel dramatically increases the production of ozone. As a product of a photochemical process, it is clear that ozone concentrations typically possess a distinct diurnal pattern, much like that of the ozoneinduced smog within Los Angeles.

High daytime concentrations of lower atmospheric ozone can adversely affect the health of humans, plants, and animals (Berman et al. 1995, Lacroix \& Lambre 1998, Gold et al. 1999). The predominant human symptoms of exposure to unhealthy levels of ozone are reduction in lung function, chest pain, and coughing, while prolonged exposure may lead to respiratory infection and lung inflammation. Portions of the human population that are most at risk are children (prolonged exposure) and the elderly (enhancement of pre-existing respiratory diseases). Long-term exposure may lead to irreversible changes in lung structure and chronic respiratory illnesses.

Unhealthy levels of lower atmospheric ozone across the Phoenix urban area have been a focus of attention for the United States Environmental Protection Agency (EPA) over the past decade. Traditionally, the EPA has categorized low-level ozone as dangerous if the concentration exceeds 0.12 parts per million (ppm) over the course of $1 \mathrm{~h}$. Phoenix failed to meet the healthbased $1 \mathrm{~h}$ air quality standard by the Clean Air Act deadline of November 15, 1996 (US EPA 1998). As a result, the EPA reclassified the Phoenix metropolitan ozone nonattainment area from 'moderate' to 'serious'. In 1997, the EPA revised the federal ozone standard from $0.12 \mathrm{ppm}$ averaged over $1 \mathrm{~h}$ to $0.08 \mathrm{ppm}$ averaged over 8 h (US EPA 1998). Phoenix ozone levels have remained fairly stable over the past few years despite rapid population growth. Still, lower atmospheric ozone levels are often unhealthy, with the highest concentrations consistently located over the eastern portion of the Phoenix urban area across Mesa, Arizona (Fig. 1b), during the summer months (US EPA 1998).

Although aerosol dispersion has been modeled (e.g. Oke 1973, Arnfield 1982, Berman et al. 1995, Loibi 1997), there has been a lack of studies that have 
focused upon analyzing the actual transport of ozone (e.g. Comrie 1996), in which case model concerns about maintaining particulate integrity is not a problem (M cRae et al. 1982). Several studies have used statistical analyses to identify associations between synoptic-scale circulation regimes and general pollutant concentrations within particular urban areas (Kalkstein \& Corrigan 1986, Davis \& Kalkstein 1990, Davis \& Rogers 1992, Davis \& Gay 1993, Comrie 1996). However, few studies have attempted to stratify the transport of ozone by the condition of the atmosphere on varying spatial scales. This is despite the fact that several studies of atmospheric circulation have indicated the significance of energy exchanges between synoptic-, meso- and microscale systems (Rowson \& Colucci 1992, McCollum et al. 1995, Douglas \& Li 1996, Rodwell \& Hoskins 1996).

Due to high ozone concentrations and the physical geography of the region (Fig. 1a), the Phoenix area is conducive to the study of the relationship between the transport of lower atmospheric ozone and varying micro-, meso-, and synoptic-scale atmospheric conditions. Phoenix is particularly appealing as a platform of study during the late summer season when the southwest monsoon circulation is active (J urwitz 1953, Bryson \& Lowry 1955, Hales 1974, Carleton 1986, Harrington et al. 1992, Farfan \& Zehnder 1994, Adams \& Comrie 1997). The flow of moist air across the Phoenix area from the south often occurs in surges triggered by synoptic-scale events (Carleton 1986), resulting in varying amounts of humidity through time and significant variations in the micro- and mesoscale meteorology of the area.

The objective of the case study that is presented here was to identify factors governing the transport of lower atmospheric ozone across the eastern portion of the Phoenix Valley during mid-to-late summer 1998. Included is the study of the boundary layer climate at a location within the eastern portion of the Phoenix area, and its contribution to initiating a thermal mesoscale circulation capable of transporting ozone. In assessing the mesoscale transport of ozone, a mesoscale network of lower atmospheric ozone and meteorological data for the Phoenix valley area were analyzed. The background synoptic-scale atmospheric situation was assessed in an attempt to determine its impact on the concentration of lower atmospheric ozone in the area, including its influence on the embedded circulation systems across Phoenix.

\section{DATA AND METHODOLOGY}

2.1. Microclimatic forcings. The chosen site for the study is located on the grounds of a regional airport
(Falcon Field, Mesa; Fig. 1a,b) that supports flight activity of small aircraft. The surface of the site is characterized by a mixture of short, dry desert grasses and an exposed clay-sand soil. The particular site was chosen due to its location within an area of consistently high afternoon ozone readings and because it offered a study platform with a surrounding wind fetch of at least $100 \mathrm{~m}$ over the same surface type. Therefore, study of the microclimate of this area is believed to be reasonably representative of the local area within which high ozone levels are common.

In order to characterize the lower atmosphere, a tower for the support of micrometeorological instruments was erected to a height of $6 \mathrm{~m}$. Sensors for measuring air temperature $\left({ }^{\circ} \mathrm{C}\right)$, relative humidity $(\%)$, and wind speed $\left(\mathrm{m} \mathrm{s}^{-1}\right)$ were fixed at logarithmic heights of $0.6,1.7$, and $5.0 \mathrm{~m}$. A wind vane fixed atop the tower detected wind direction (degrees). Within $10 \mathrm{~m}$ of the tower, a separate, smaller tower was erected to a height of $1 \mathrm{~m}$. This second tower supported instrumentation for measuring barometric pressure $(\mathrm{mb})$, total solar radiation $\left(\mathrm{W} \mathrm{m}^{-2}\right)$, reflected solar radiation $\left(\mathrm{W} \mathrm{\textrm {m } ^ { - 2 }}\right.$ ), net radiation (shortwave and longwave; $\mathrm{W}$ $\left.\mathrm{m}^{-2}\right)$, and surface infrared temperature $\left({ }^{\circ} \mathrm{C}\right)$. All towersupported instruments were leveled and calibrated for accuracy, and also checked daily for high operational performance. Within $10 \mathrm{~m}$ of the second tower, soil thermistors for measuring soil temperature $\left({ }^{\circ} \mathrm{C}\right)$ were buried at depths of $0.01,0.15$, and $0.25 \mathrm{~m}$, while 2 heat flux transducers for measuring soil heat flux $\left(\mathrm{W} \mathrm{m}^{-2}\right)$ were buried at depths of 0.03 and $0.14 \mathrm{~m}$. For each instrument except the wind vane, measurements were taken at an interval of $5 \mathrm{~s}$, averaged over an interval of $5 \mathrm{~min}$, and recorded to automated dataloggers. Wind direction measurements were simply recorded at the end of each 5 min interval. Data acquisition began on J uly 11 and ended on September 12 .

In coordination with the microclimatic data collection, scientists from the Arizona Department of Environmental Quality (ADEQ) recorded on-site ozone concentrations using air chemistry analyzers positioned at a height of $6 \mathrm{~m}$. Data were collected at $1 \mathrm{~min}$ intervals and subsequently calculated to $1 \mathrm{~h}$ averages (centered on each half-hour) in order to coincide with the temporal criterion for EPA evaluation ( $8 \mathrm{~h}$ average from hourly measurements).

Once the ozone data were collected for the period of study, the group of study days was stratified into 3 categories based on the daily $8 \mathrm{~h}$ average ozone concentration from 11:30 h local standard time (LST) (11:00 to 11:59 h LST average) through 18:30 h LST (18:00 to 18:59 h LST average). The first category, high ozone, includes days possessing an $8 \mathrm{~h}$ average ozone concentration of $0.08 \mathrm{ppm}$ (EPA exceedance level) or greater. The intermediate category, moderate ozone, 
includes days possessing an $8 \mathrm{~h}$ average concentration of greater than or equal to $0.07 \mathrm{ppm}$, but less than $0.08 \mathrm{ppm}$. The final category, low ozone, is composed of days possessing an $8 \mathrm{~h}$ average ozone concentration of less than $0.07 \mathrm{ppm}$. Stratifying the days based on an $8 \mathrm{~h}$ concentration of $0.07 \mathrm{ppm}$ produced a nearly even division of the study days. The $0.08 \mathrm{ppm}$ value evenly divided the upper division and, in essence, distinguished the higher ozone days in terms of whether or not the EPA standard was exceeded. For each of the 3 categories, a simple composite of the hourly ozone concentrations through a full $24 \mathrm{~h}$ period was constructed by averaging the hourly ozone measurements for each day that fell into that category. The product was an hourly diurnal composite of ozone concentration for a high, a moderate, or a low ozone day at the study site in M esa.

Once each day of the study period was qualified as a high, moderate, or low ozone day, intercomparisons of the microclimate of the area (as recorded at the study site) through the course of each type of day were made. Study of the microclimatic differences included analysis of: total insolation; net radiation; surface pressure; surface, air, and dew point temperatures (calculated from relative humidity, air temperature, and surface pressure); wind speed and direction; and lowlevel vertical gradients of temperature and moisture. Each of the different parameters, except wind direction, were hourly averaged and used to create a diurnal composite for each of the 3 ozone categories. Diurnal intercomparisons were made by calculating the difference between the hourly composite values associated with each of the 3 ozone categories. Composites of the hourly wind direction were expressed in terms of the percentage of measurements for which the wind

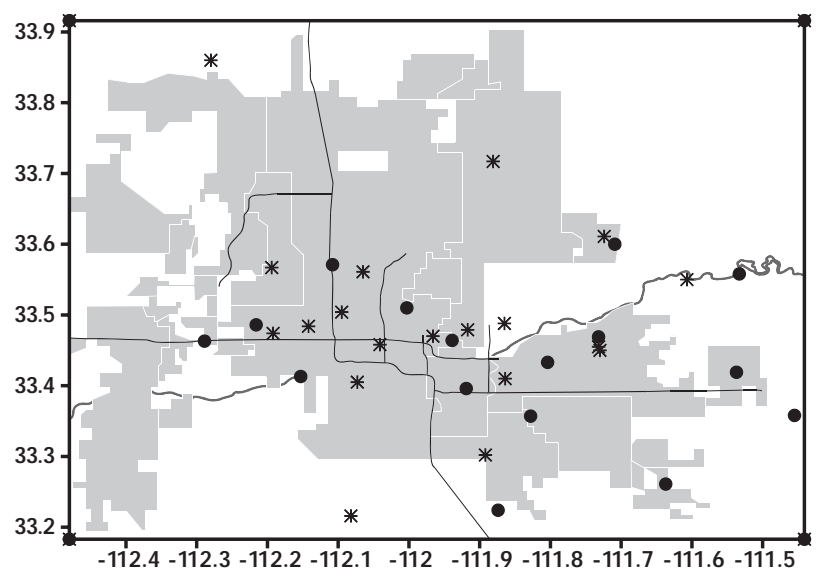

Fig. 2. Locations of the 16 PRISMS meteorological stations (•) and the 19 ozone monitoring stations (*) across the Phoenix metropolitan area direction fell into each octant (i.e. a wind rose): north, northeast, east, southeast, south, southwest, west, and northwest.

In order to quantify the within-category similarity of the ozone and atmospheric conditions that characterize the days that comprise each ozone category (high, moderate, low), several statistics were calculated using daily data from the critical $8 \mathrm{~h}$ period 11:00 to 19:00 $\mathrm{h}$ LST. M eans, standard deviations, and simple box plots of the data were constructed in order to show simple differences between the categories, while unpaired 2-sample t-tests were performed in order to show the significance of the differences.

\subsection{Mesocale circulation}

To associate the microclimate of the eastern Phoenix area with the mesoscale circulation of ozone, the spatial patterns of ozone and meteorological parameters for the full eastern Phoenix Valley area were analyzed. Based upon the stratification of days as dictated by the ozone data collected at the microclimate site, spatial distributions of diurnal composite values of ozone and lower atmospheric meteorological parameters were constructed for high, moderate, and low ozone days. In addition to the data recorded at the microclimate site, hourly averaged ozone data were taken as a subset of larger data sets maintained by ADEQ and the Maricopa County Air Quality Division. The subsequent data set is composed of a relatively even distribution of 19 stations at which ozone was monitored during the period of study (Fig. 2). Hourly meteorological data for the area were taken as a subset of the Phoenix Realtime Instrumentation for Surface M eteorology Studies (PRISM S) database to form a distribution of 16 stations across the Phoenix valley (Fig. 2). From each station and for the period of study, wind speed and wind direction data were extracted for analysis.

Ozone, wind speed, and wind direction data for each day within each of the 3 ozone categories were included in a diurnal composite for each station of the mesoscale network. The hourly composite values were interpolated to a grid covering the Phoenix Valley. Over the area, 16 cells represent a $4 \times 4$ grid that produces a cell resolution of approximately $0.25^{\circ}$ longitude by $0.19^{\circ}$ latitude, across which the point data was interpolated using an inverse distance squared technique. Spatial comparisons between the composite values associated with the 3 ozone categories were made. As with the wind direction data collected at the microclimate site, hourly frequency distributions for each octant of wind direction were calculated for each ozone category at each station of the mesoscale network. The predominant wind direction at each hour 
was combined with the hourly average wind speed to produce a vector of the predominant wind. Differences between the mesoscale ozone transport and meteorological characteristics associated with the 3 ozone categories were then analyzed in the context of the potential contribution made by the characteristic microclimate of each category.

\subsection{Background synoptic circulation}

After analyzing the relationships between ozone concentrations and the condition of the lower atmosphere across the micro- and mesoscales, the background synoptic circulation within which the smaller climatic forcings were embedded was analyzed. This portion of the study examined the synoptic circulation for its contribution to the general level of ozone concentration and its transport across the Phoenix Valley. Composite maps of $500 \mathrm{mb}$ geopotential height, $850 \mathrm{mb}$ wind direction, wind speed, and specific humidity were constructed for the high, moderate, and low ozone categories. The data and software for the analysis were obtained from the Climate Diagnostics Center (CDC), which makes use of the National Center for Environmental Prediction (NCEP) reanalysis data. Differences between the general patterns associated with the 3 categories were identified and related to the associated micro- and mesoscale atmospheric conditions across the Phoenix Valley.

\section{RESULTS AND ANALYSIS}

\subsection{Microclimatic forcings}

Over the course of the $64 \mathrm{~d}$ study period, the on-site equipment for analyzing the atmospheric concentration of ozone within Mesa was operational for 43 days (non-operational from July 28 to August 17). Of the 43 days, 11 days were classified as high ozone days (EPA exceedance), 10 as moderate ozone days, and 22 as low ozone days. Over the course of the study period there was no preferred day of the week or preferred timing within the 2 mo period for either category, but instead a rather even distribution on all accounts. In fact, all but 3 of the days that fell in the low ozone category were evenly distributed across the 5 weekdays, and not on weekends, when automobile use was likely lessened. Also, as would be expected, the transition from one ozone category to another on successive days nearly always included the moderate ozone category. In other words, rarely (4 occasions) were successive days classified as one being of high ozone concentration and one of low ozone.
Table 1. M eans and standard deviations of the ozone and surface meteorological conditions for the $8 \mathrm{~h}$ period used for daily ozone classification (11:00 to 19:00 h LST). Standard deviations are given in parentheses. The variables include ozone $\left(\mathrm{O}_{3} ; \mathrm{ppm}\right)$, dew point temperature $\left(\mathrm{T}_{\mathrm{d}} ;{ }^{\circ} \mathrm{C}\right)$, total insolation $\left(\mathrm{Q}_{\mathrm{t}} ; \mathrm{Wm}^{-2}\right)$, surface temperature $\left(\mathrm{T}_{\mathrm{g}} ;{ }^{\circ} \mathrm{C}\right)$, air temperature $\left(\mathrm{T}_{\mathrm{a}} ;{ }^{\circ} \mathrm{C}\right)$, pressure $(\mathrm{P} ; \mathrm{mb})$, wind speed $\left(|\mathrm{v}| ; \mathrm{ms}^{-1}\right)$, and vertical gradients (5.0 to $0.6 \mathrm{~m})$ of air temperature $\left(\mathrm{T}_{\mathrm{a} 500}-\mathrm{T}_{\mathrm{a} 60} ;{ }^{\circ} \mathrm{C}\right)$ and dew point temperature $\left(\mathrm{T}_{\mathrm{d} 500}-\mathrm{T}_{\mathrm{d} 60} ;{ }^{\circ} \mathrm{C}\right)$

\begin{tabular}{|lccc|}
\hline Variable & High & Moderate & \multicolumn{1}{c|}{ Low } \\
\hline $\mathrm{O}_{3}$ & $0.088(0.004)$ & $0.076(0.003)$ & $0.059(0.009)$ \\
$\mathrm{T}_{\mathrm{d}}$ & $11.00(3.46)$ & $13.17(3.36)$ & $14.67(3.73)$ \\
$\mathrm{Q}_{\mathrm{t}}$ & $702.1(109.57)$ & $682.1(95.93)$ & $572.9(141.11)$ \\
$\mathrm{T}_{\mathrm{g}}$ & $56.19(2.95)$ & $52.96(3.28)$ & $45.84(6.94)$ \\
$\mathrm{T}_{\mathrm{a}}$ & $41.97(2.27)$ & $39.14(2.72)$ & $36.05(4.00)$ \\
$\mathrm{P}$ & $960.36(0.10)$ & $960.93(0.19)$ & $960.71(0.41)$ \\
$|\mathrm{V}|$ & $2.87(0.22)$ & $2.95(0.51)$ & $3.35(0.87)$ \\
$\mathrm{T}_{\mathrm{a} 500}-\mathrm{T}_{\mathrm{a} 60}$ & $-1.49(0.08)$ & $-1.49(0.16)$ & $-1.24(0.27)$ \\
$\mathrm{T}_{\mathrm{d} 500}-\mathrm{T}_{\mathrm{d} 60}$ & $0.47(0.31)$ & $0.25(0.23)$ & $0.18(0.25)$ \\
\hline
\end{tabular}

In referencing the general climate of central Arizona over the course of the study period to long-term climatic averages through the period, surface air temperatures were consistently higher than is typical $(+0.2$ to $\left.1.0^{\circ} \mathrm{C}\right)$, as were dew point temperatures $\left(+0.5\right.$ to $\left.1.0^{\circ} \mathrm{C}\right)$. Likewise, over the course of the study period ozone values within the Phoenix Valley were near normal overall, but with fewer federal exceedances than in previous years.

During the $8 \mathrm{~h}$ period 11:00 to 19:00 h LST, the average concentration of ozone on high ozone days during the study period was $0.012 \mathrm{ppm}$ higher than on moderate ozone days, and was $0.029 \mathrm{ppm}$ higher than on low ozone days (Table 1 ). Box plots of the $8 \mathrm{~h}$ data from each day of each category show the within-category similarity of the ozone concentration (Fig. 3a). The data for each category is very distinct from those of the others, the significance of which is quantified by an unpaired 2-sample t-test (Table 2), which indicates this conclusion with a significance level of 0.001 . Diurnal composites of ozone show maximum concentrations occurring progressively later in the afternoon as the $8 \mathrm{~h}$ ozone average increases from a low ozone day (13:30 h LST) to a high ozone day (16:30 h LST; Fig. 4a). As the microclimate site is situated east of the Phoenix urban center, the later maximum concentration on high ozone days may be a product of eastward ozone transport. Therefore, while the maximum ozone concentration is dependent upon insolation, it is likely that it is also dependent on positive advection of ozone as well.

In examining the differences between the composites of the microclimates of the 3 ozone categories, it is apparent that there existed a striking difference in the 

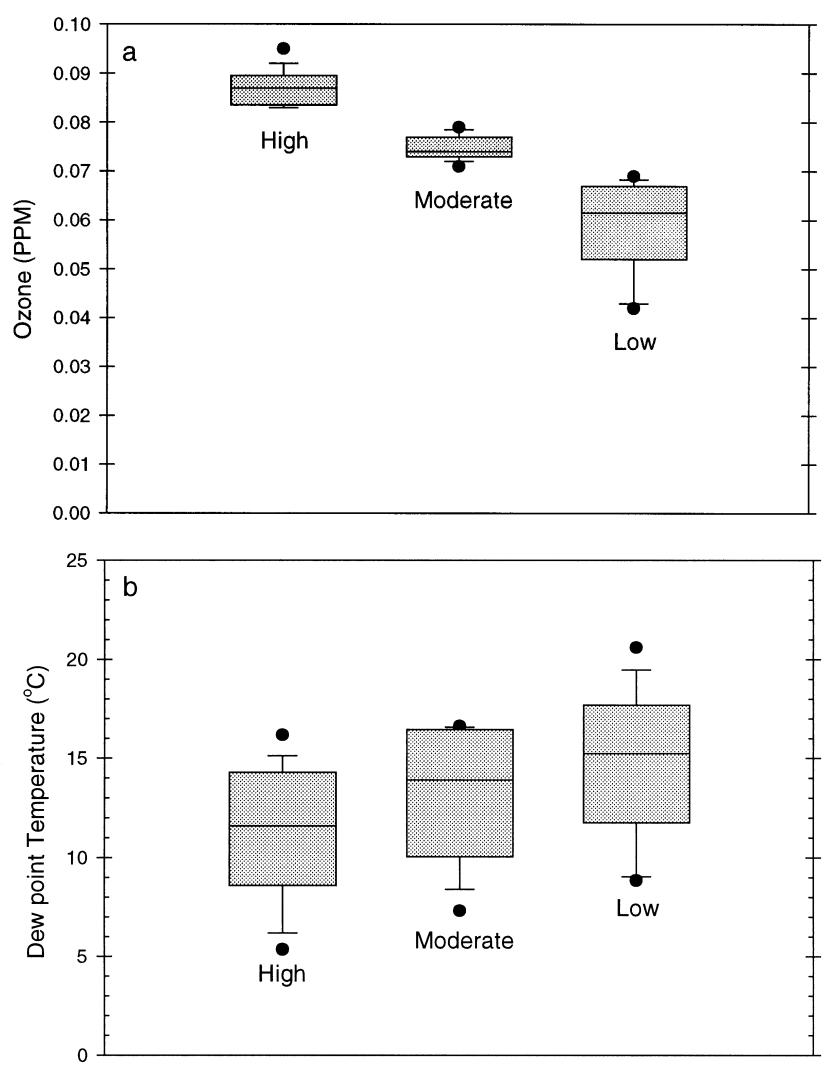

Fig. 3. Box plots of (a) ozone and (b) dew point temperature for each of the 3 ozone categories during the period 11:00 to 19:00 h LST. The median, 10th, 25th, 75th, and 90th percentiles, and maxima and minima are indicated

lower atmospheric $(1.7 \mathrm{~m})$ moisture on the days of each category. Consistently through the diurnal period, composite values of dew point temperature were 3 to $4^{\circ} \mathrm{C}$ lower on high ozone days rather than low ozone days, and 1 to $2^{\circ} \mathrm{C}$ lower than on moderate ozone days (Fig. 4b, Table 1). The degree to which the dew point temperature data of each category (Fig. 3b) are distinct from those of the other categories is, at minimum, significant at the 0.10 level (Table 2). Additionally, light convective afternoon rainfall events (all less than $0.5 \mathrm{~cm}$ ) occurred on 4 days, all of which fell into the category of low ozone concentration.

The decreased water vapor on days of high ozone had an expected impact on the amount of insolation reaching the surface (Table 1 ), with the midday composite value of insolation higher by approximately $200 \mathrm{~W} \mathrm{~m}^{-2}$ on high ozone days rather than on low ozone days (Fig. 4c). Interestingly, insolation was only slightly larger on high ozone days rather than moderate ozone days (Table 1). Therefore, the degree to which the insolation data associated with each category are distinct from those of the other categories (Table 2) is most significant between the groups of days associated with high and low ozone concentrations. It should be noted that in measuring a variable such as insolation at a point location, and making use of a small sample of days, a single anomaly (e.g. a cumulus cloud) could have had a large impact on the diurnal composite. However, for each of the 3 ozone categories, the daytime patterns of the insolation composites were relatively smooth (Fig. 4c).

A primary product of higher amounts of insolation on high ozone days was an increase in ground surface temperatures (Table 1). On average, surface temperatures were as much as $11^{\circ} \mathrm{C}$ warmer between $12: 30$ and 14:30 h LST on high ozone days rather than low ozone days (not shown). The difference between surface temperatures on high and moderate ozone days was smaller (Table 1), with a maximum difference of approximately $3^{\circ} \mathrm{C}$ during mid-afternoon (not shown). The t-test statistics show the differences between the categories to be meaningful at better than a 0.03 level (Table 2). Through conduction and convection of greater amounts of heat from the surface on high ozone days, overlying surface air temperatures at $1.7 \mathrm{~m}$ were highest on days of high ozone (Table 1 ). On average, late afternoon (17:30 h LST) surface air

Table 2. $t$ value and level of significance for the unpaired 2-sample t-test between the ozone and primary meteorological variables associated with the 3 ozone categories. Variable abbreviations are the same as for Table 1 . *Significance at the $p=0.05$ level

\begin{tabular}{|c|c|c|c|}
\hline Variable & Pair & $\mathrm{t}$ & Significance \\
\hline $\mathrm{O}_{3}$ & $\begin{array}{l}\text { High-moderate } \\
\text { High-low } \\
\text { Moderate-low }\end{array}$ & $\begin{array}{l}7.717 \\
9.309 \\
4.940\end{array}$ & $\begin{array}{l}0.001^{*} \\
0.001^{*} \\
0.001^{*}\end{array}$ \\
\hline$T_{d}$ & $\begin{array}{l}\text { High-moderate } \\
\text { High-low } \\
\text { Moderate-low }\end{array}$ & $\begin{array}{l}-1.881 \\
-5.163 \\
-3.111\end{array}$ & $\begin{array}{l}0.093 \\
0.001^{*} \\
0.012^{*}\end{array}$ \\
\hline $\mathrm{Q}_{\mathrm{t}}$ & $\begin{array}{l}\text { High-moderate } \\
\text { High-low } \\
\text { Moderate-low }\end{array}$ & $\begin{array}{l}1.953 \\
2.440 \\
1.653\end{array}$ & $\begin{array}{l}0.083 \\
0.037^{*} \\
0.133\end{array}$ \\
\hline $\mathrm{T}_{\mathrm{g}}$ & $\begin{array}{l}\text { High-moderate } \\
\text { High-low } \\
\text { Moderate-low }\end{array}$ & $\begin{array}{l}2.518 \\
3.876 \\
2.634\end{array}$ & $\begin{array}{l}0.033^{*} \\
0.003^{*} \\
0.027^{*}\end{array}$ \\
\hline $\mathrm{T}_{\mathrm{a}}$ & $\begin{array}{l}\text { High-moderate } \\
\text { High-low } \\
\text { Moderate-low }\end{array}$ & $\begin{array}{l}3.183 \\
4.665 \\
2.865\end{array}$ & $\begin{array}{l}0.011^{*} \\
0.001^{*} \\
0.019^{*}\end{array}$ \\
\hline$|v|$ & $\begin{array}{l}\text { High-moderate } \\
\text { High-low } \\
\text { Moderate-low }\end{array}$ & $\begin{array}{l}-0.381 \\
-1.013 \\
-0.665\end{array}$ & $\begin{array}{l}0.712 \\
0.335 \\
0.522\end{array}$ \\
\hline $\mathrm{T}_{\mathrm{a} 500^{-}} \mathrm{T}_{\mathrm{a} 60}$ & $\begin{array}{l}\text { High-moderate } \\
\text { High-low } \\
\text { Moderate-low }\end{array}$ & $\begin{array}{r}0.314 \\
-1.500 \\
-1.388\end{array}$ & $\begin{array}{l}0.761 \\
0.164 \\
0.198\end{array}$ \\
\hline$T_{d 500}-T_{d 60}$ & $\begin{array}{l}\text { High-moderate } \\
\text { High-low } \\
\text { M oderate-low }\end{array}$ & $\begin{array}{l}1.952 \\
2.569 \\
0.779\end{array}$ & $\begin{array}{l}0.083 \\
0.028^{*} \\
0.456\end{array}$ \\
\hline
\end{tabular}



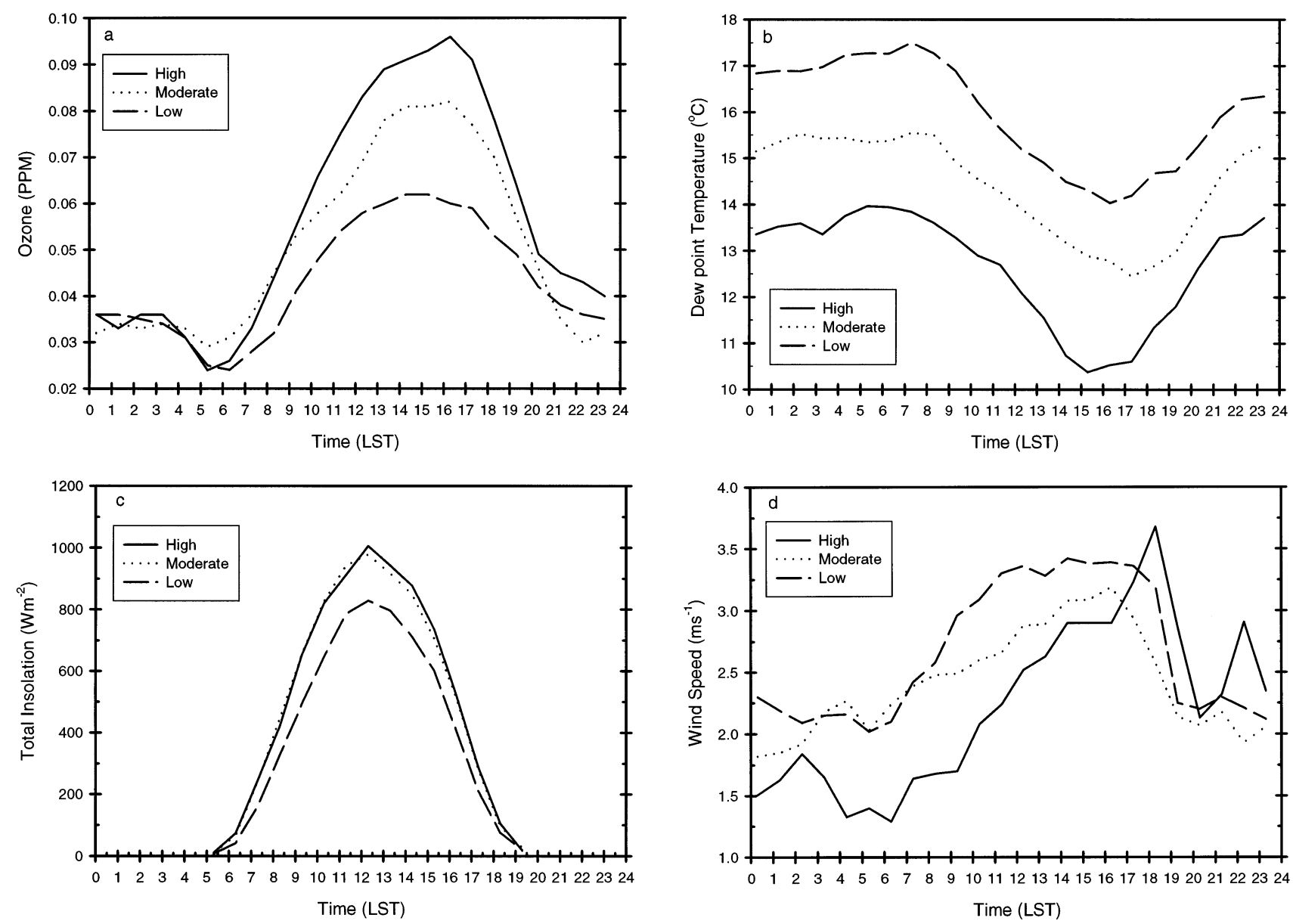

Fig. 4. Diurnal time series of composite values of ozone and microclimate variables for high, moderate, and low ozone categories. Variables are (a) ozone, (b) dew point temperature at $1.7 \mathrm{~m}$, (c) total insolation, and (d) wind speed at $1.7 \mathrm{~m}$

temperatures were $6^{\circ} \mathrm{C}$ higher on high ozone days rather than low, and $2.5^{\circ} \mathrm{C}$ higher than on moderate ozone days (not shown). As with surface temperatures, the differences in the air temperature data associated with the 3 ozone categories are shown to be important at a significance level of better than 0.05 (Table 2). Warmer surface and air temperatures on high ozone days resulted in only very small decreases in afternoon surface pressures (Table 1), with a maximum difference of less than $1 \mathrm{mb}$ between high and both moderate and low ozone days between 15:30 and 17:30 h LST (not shown).

Taken together, drier air, greater insolation, and warmer surface and air temperatures could have a marked effect on thermally induced circulations within the Phoenix Valley. It is reasonable to think that the enhanced insolation and warming associated with the drier atmospheric characteristics of high ozone days would have been more dramatic on the southwestward facing slopes of the higher terrain northeast of Phoenix (Fig. 1a). It is hypothesized that an organized upslope thermal circulation could aid in the transport of ozone from the urban center of Phoenix eastward, across the eastern suburb of M esa.

Diurnal composites of wind speed for each of the 3 ozone categories (Fig. 4d) show the lower atmosphere to have been most dynamic on low ozone days, and most stagnant on high ozone days, until early evening (18:30 h LST). The differences in wind speed are also evident in the daytime averages (Table 1 ), where the value on low ozone days is $0.48 \mathrm{~m} \mathrm{~s}^{-1}$ greater than on high ozone days. Toward sunset, average wind speeds lessen within the moderate and low ozone categories, but reach a maximum within the high ozone category (Fig. 4d). This may be a function of the magnitude of late-day instability on the very warm days of high ozone. Interestingly, a secondary peak in wind speed (22:30 h LST) is evident on high ozone days (Fig. $4 \mathrm{~d}$ ). This may or may not have been the product of cool air drainage from the higher terrain after rapid nighttime cooling of the very dry air associated with high ozone days. Interestingly, the wind speeds that are character- 

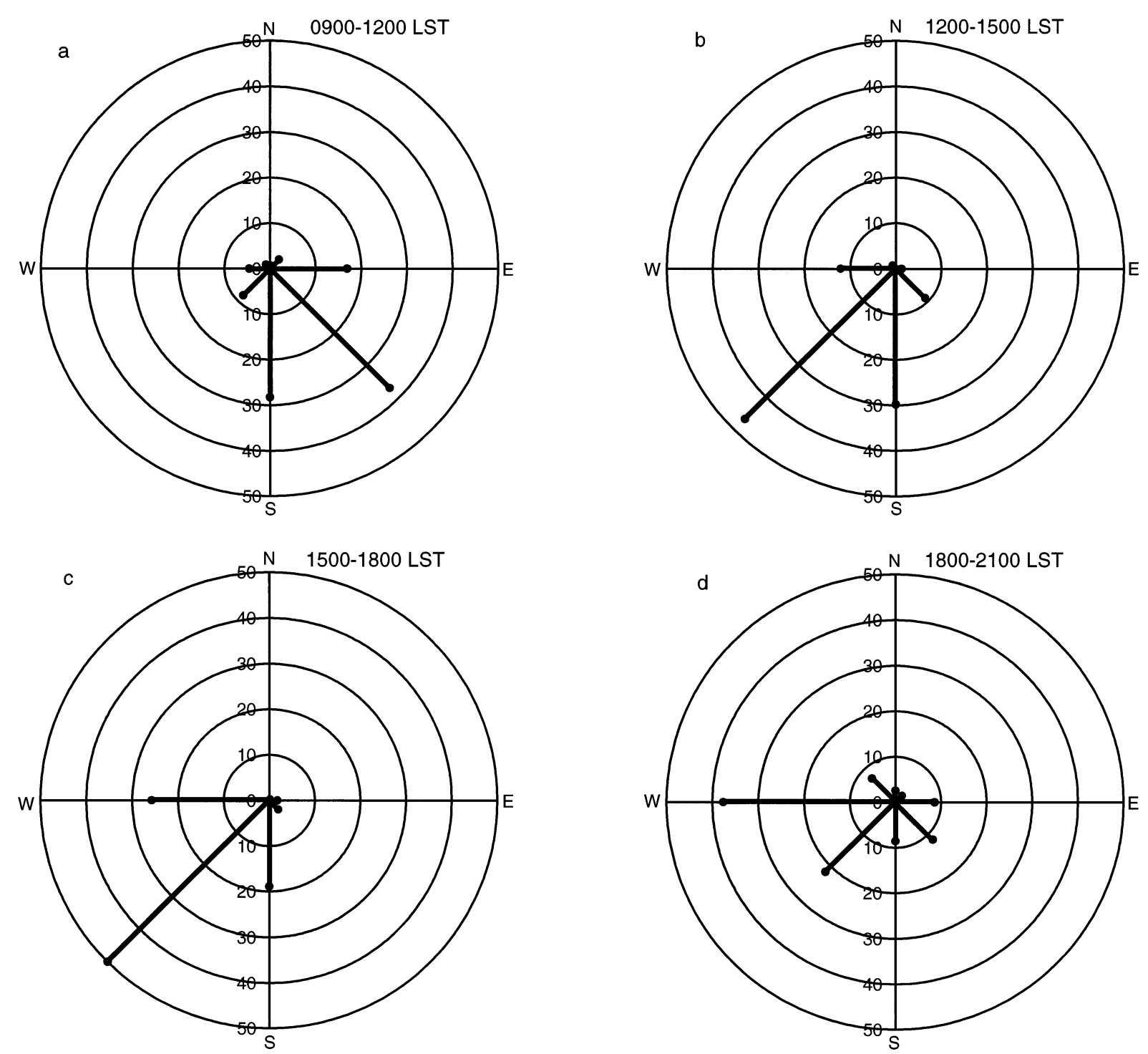

Fig. 5. Wind roses showing the percent frequency of occurrence of wind direction during $3 \mathrm{~h}$ periods on days of high ozone. Periods shown are (a) 09:00-12:00 h LST, (b) 12:00-1500 h LST, (c) 15:00-18:00 h LST, and (d) 18:00-21:00 h LST

istic of each of the 3 ozone categories are not significantly different (Table 2). This is surprising considering that high ozone concentrations are generally thought to be partially a product of limited lower atmospheric mixing, and consequently lower wind speeds.

Further evidence of weaker wind speeds in the lower atmosphere on high and moderate ozone days lies within the diurnal composites of temperature and moisture profiles between the heights of 5.0 and $0.6 \mathrm{~m}$. The daytime lapse atmosphere was greatest for high and moderate ozone days, while a daytime moisture inversion was greatest on high ozone days (Table 1). This indicates that mixing of the lower atmosphere was likely to have been less on days of high and/or moder- ate ozone, which, again, is a key factor in the lower atmospheric concentration of a gas such as ozone. The unpaired 2-sample t-test indicates a high level of significance in distinguishing the vertical gradient of dew point temperature on high ozone days from that on low ozone days (Table 2). There exists very little significance in distinguishing the vertical gradient of lower atmospheric air temperature between any of the 3 ozone categories (Table 2).

The diurnal distributions of wind direction for the 3 ozone categories indicate the presence of organized flow through the microclimate site on days of high and moderate ozone. Wind roses indicating the percent frequency of wind direction measured at a 5 min interval through $3 \mathrm{~h}$ periods of all of the days in each ozone cat- 

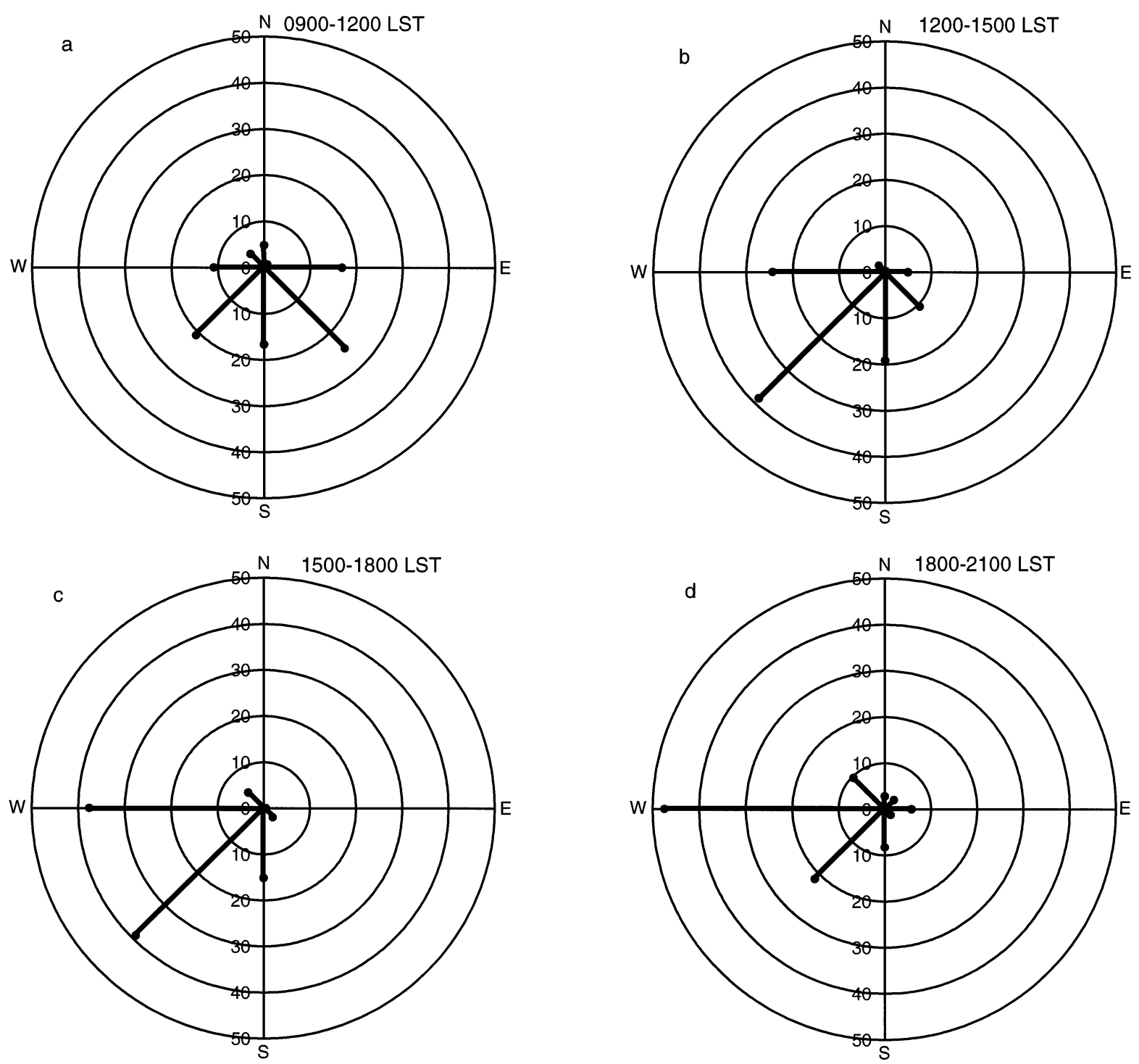

Fig. 6. Wind roses showing the percent frequency of occurrence of wind direction during $3 \mathrm{~h}$ periods on days of moderate ozone

egory were analyzed. The wind roses show relatively variable winds from 00:00 to 09:00 h LST in all 3 categories (not shown). For all 3 categories, high, moderate and low ozone days, the predominant wind directions during those early morning hours were northeast and east. This agrees with the idea of a thermal circulation within the valley, in that easterly-northeasterly flow from the higher elevations to the east should be predominant on nights that possess a weak background synoptic flow. Over the course of the next $3 \mathrm{~h}$ period, 09:00 to 12:00 h LST, an average south-southeast wind direction becomes predominant on high ozone days (>75\%; Fig. 5a), while only on a moderate frequency does this directional preference occur on moderate (Fig. 6a) and low ozone days (Fig. 7a). Between 12:00 and 15:00 $\mathrm{h}$ LST, the winds on high and moderate ozone days showed strong signs of veering through time. The predominant wind direction became southerly-southwesterly on high ozone days (Fig. 5b), and southwesterly-westerly on moderate ozone days (Fig. 6b). On low ozone days the average wind direction remained variable, but typically possessed an easterly-southeasterly component (Fig. 7b).

During the time period of maximum ozone concentration on high ozone days (15:00 to 18:00 h LST), the wind direction at the microclimate site was most frequently from the southwest or west on high (Fig. 5c) and moderate (Fig. 6c) ozone days. The wind direction on low ozone days during this $3 \mathrm{~h}$ time period remained variable, but the direction was predominantly 

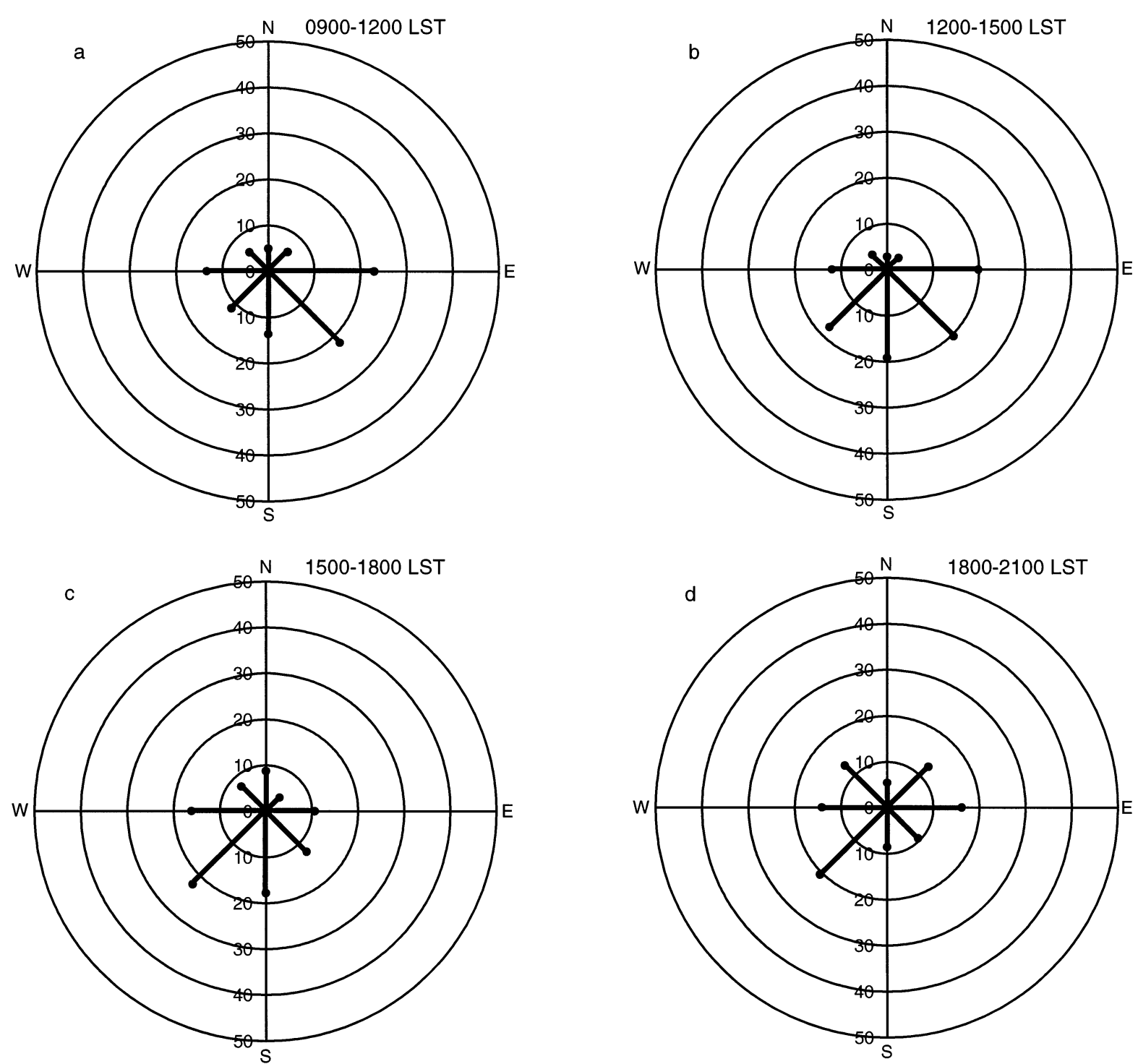

Fig. 7. Wind roses showing the percent frequency of occurrence of wind direction during $3 \mathrm{~h}$ periods on days of low ozone

southerly-southwesterly (<40\%; Fig. 7c). The veering pattern of wind direction over time continued during the early evening hours, as the direction during the period 18:00 to 21:00 h LST was from the west for nearly one-half of the observations on high (Fig. 5d) and moderate ozone days (Fig. 6d). During early evening on low ozone days, the wind direction was highly variable but predominantly from the southwest (Fig. 7d). Over the course of the last $3 \mathrm{~h}$ of the diurnal period (not shown), the direction of the winds associated with each of the 3 ozone categories closely resembled that of the early morning period. Winds were variable, but were predominantly from the northeast and east. In testing the extent to which the three ozone categories were distinguishable based upon wind direc- tion over the course of the period 11:00 to 19:00 h LST, the unpaired 2-sample t-test was performed on the data used to construct the wind roses (not shown). Only comparisons of the frequency of westerly winds between high and moderate ozone categories and the frequency of southwesterly winds between high and low ozone categories were significant at better than the $10 \%$ level.

The differences in the average microscale thermal characteristics of the 3 ozone categories were associated with noticeable differences in the diurnal wind regimes of high, moderate, and low ozone days. Days possessing high afternoon ozone concentrations were characterized by low wind speeds (less mixing) and veering of the predominant wind through time, from 
southerly-southeasterly in mid-morning, to westerlysouthwesterly in late afternoon and early evening. The veering of the wind through the day may have been a product of a thermally induced upslope circulation toward the higher terrain located east-northeast of the microclimate site (Fig. 1a). Westerly-southwesterly winds were most predominant in mid- to late afternoon, when insolation would have been most focused on the westward facing slopes of the higher terrain. The diurnal wind regime on moderate ozone days closely resembled that of high ozone days, although the veering of the winds through the daytime hours was somewhat less distinct, and wind speeds were consistently higher (greater mixing). On days of low ozone concentrations, the wind direction showed no strong evidence of veering through the day, but instead was rather variable. The greatest average wind speeds were associated with days of low ozone, which likely produced greater mixing of the lower atmosphere and possibly a greater dispersion of the ozone.

\subsection{Mesoscale circulation}

Hourly maps of the spatial distribution of lower atmospheric ozone and vectors of the predominant wind (predominant wind direction, mean wind speed) indicate the transport of ozone over the course of a high, moderate, or low ozone day as stratified by data from the microclimate site in Mesa. The spatial distribution of lower atmospheric ozone across the eastern half of the Phoenix urban area was markedly different on days of low ozone concentrations rather than moderate or high ozone concentrations. Between days of high and moderate ozone concentrations there were subtle differences in the temporal pattern of the spatial distribution of ozone through the critical $8 \mathrm{~h}$ period 11:00 to 19:00 h LST.

During the hour 11:00 to 12:00 h LST, the beginning of what appears to be an ozone plume is evident from the composite of ozone concentrations on high ozone days (Fig. 8a). The plume coincided with a generally light, westerly average wind pattern. The ozone plume became more evident as ozone concentrations increased through 14:00 $\mathrm{h}$ LST, with a maximum centered over M esa (Fig. 8b,c). Wind speeds increased in magnitude and a southwesterly component to the wind direction became slightly more frequent on average. Not surprisingly, the ozone plume extended eastward from the general area at which several major roadways intersect in Tempe (I-10, US 60, Rt. 202, Rt. 101; Fig. 1b). On days of moderate ozone concentrations, there existed no strong evidence of an ozone plume with an east-west axis through the period 11:00 to 14:00 $\mathrm{h} \mathrm{LST}$, but rather a maximum concentration of ozone forming over central Mesa (Fig. 9a-c). Wind speeds were moderately high throughout the period, and the wind directions across the eastern portion of the urban area appear to have been slightly less organized than what is shown by the composite for high ozone days. On days of low ozone concentrations, no strong spatial pattern of ozone existed on average (Fig. 10a-c). Wind speeds were relatively high throughout the period, and the predominant wind directions approximately mirrored those characteristic of moderate ozone days-generally west, but not as uniform as on days of high ozone.

During the $3 \mathrm{~h}$ period leading up to and including the ozone maximum between 16:00 and 17:00 h LST on high ozone days, the ozone plume expanded into a large centralized area of high ozone concentrations. The area of maximum ozone concentration began to flow northeastward, coinciding with stronger winds possessing more of a southwesterly component (Fig. 8d-f). The movement of the ozone was in the direction of high elevation (Fig. 1a), but locally it followed the Salt River valley (Fig. 1b). After 17:00 h LST (not shown), the average ozone concentration on high ozone days became diluted in the general area of its location between 16:00 and 17:00 h LST, at least within the Phoenix metropolitan area (no data farther northwest). On days of moderate ozone, the area of maximum ozone concentration during the period 14:00 to 17:00 h LST primarily remained over M esa, with only a limited progression to the north-northeast (Fig. 9d-f). The general flow of the atmosphere across eastern Phoenix appeared to be slightly more westward than in the case of high ozone days (southwestward), with no marked difference in the average wind speed. As was the case on high ozone days, the maximum area of ozone concentration on moderate ozone days after 17:00 h LST (not shown) became diluted in the area of its location between 16:00 and 17:00 h LST. Interestingly, the maximum ozone concentration on moderate days of ozone across the eastern metropolitan area occurred 1 to $2 \mathrm{~h}$ earlier than on high ozone days, verifying what was found at the microclimate site (Fig. 4a). Hourly composites of ozone concentration and predominant wind vectors for days of low ozone between 14:00 and 17:00 h LST indicate only a weak pattern of higher ozone concentrations in the northeast quadrant of the metropolitan area (Fig. 10d-f). Winds were relatively strong, and a northwest direction became predominant between 16:00 and 17:00 h LST. As with days of high and moderate ozone, the concentration of ozone after 17:00 h LST (not shown) on low ozone days retained the earlier spatial pattern, but lessened in magnitude.

The differences in the spatial distribution of ozone on high, moderate, and low ozone days may be further ev- 

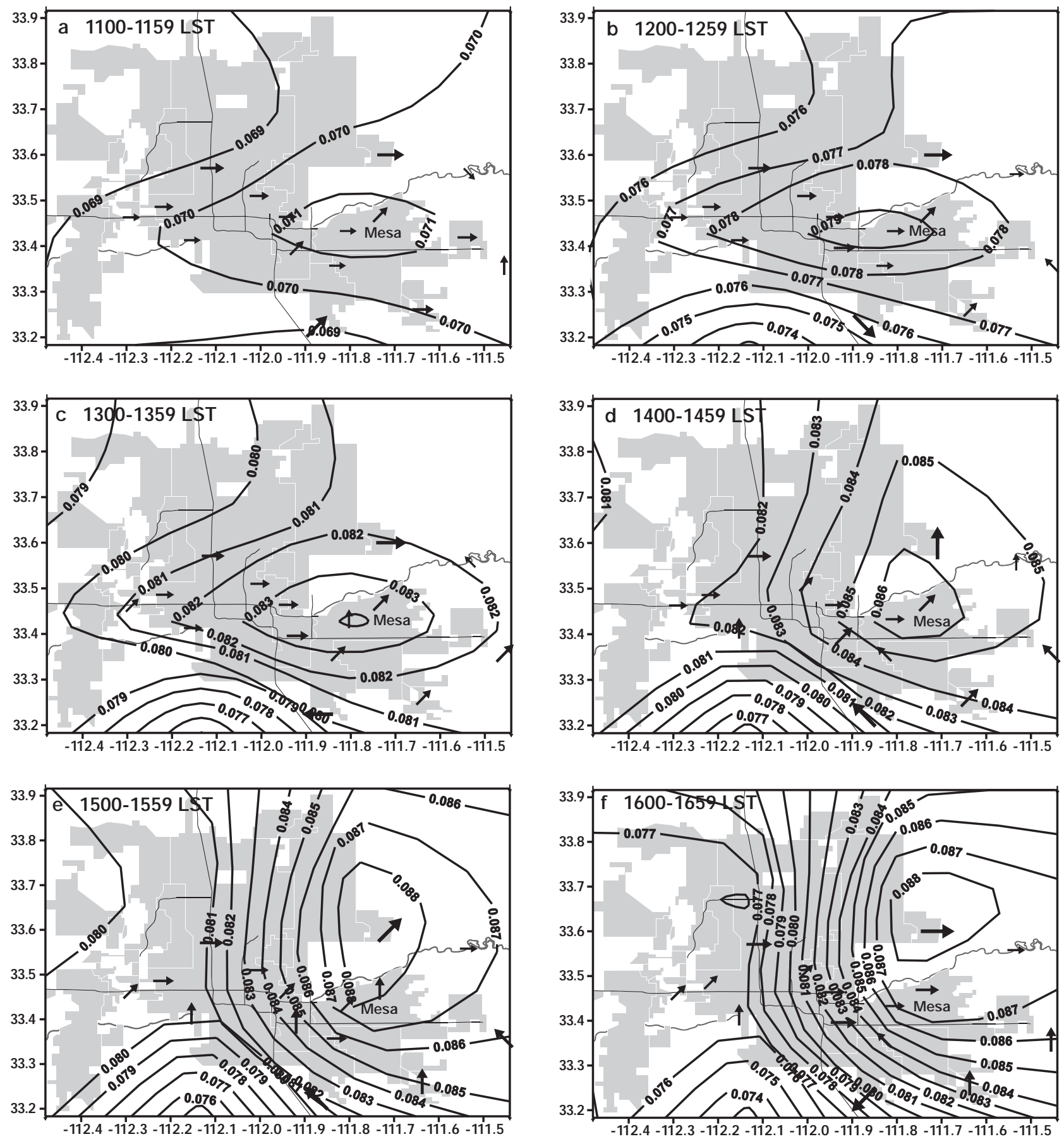

Fig. 8. Composites of ozone concentrations (ppm) and predominant wind vectors $\left(0.25 \mathrm{~cm}=1 \mathrm{~m} \mathrm{~s}^{-1}\right)$ on days of high ozone from (a) 11:00-11:59 h LST, (b) 12:00-12:59 h LST, (c) 13:00-13:59 h LST, (d) 14:00-14:59 h LST, (e) 15:00-15:59 h LST, and (f) 16:00-16:59 h LST

idence of what the microclimatic data suggest in terms of an involvement of a mesoscale thermal circulation in the transport of lower atmospheric ozone. The welldefined plume of ozone that westerly-southwesterly winds subsequently transported along the Salt River valley toward high terrain during the afternoon hours on high ozone days is indicative of such a circulation. It appears that the lower atmospheric winds were slightly more vigorous and less organized on days of moderate ozone, and even more so on days of low ozone concen- 

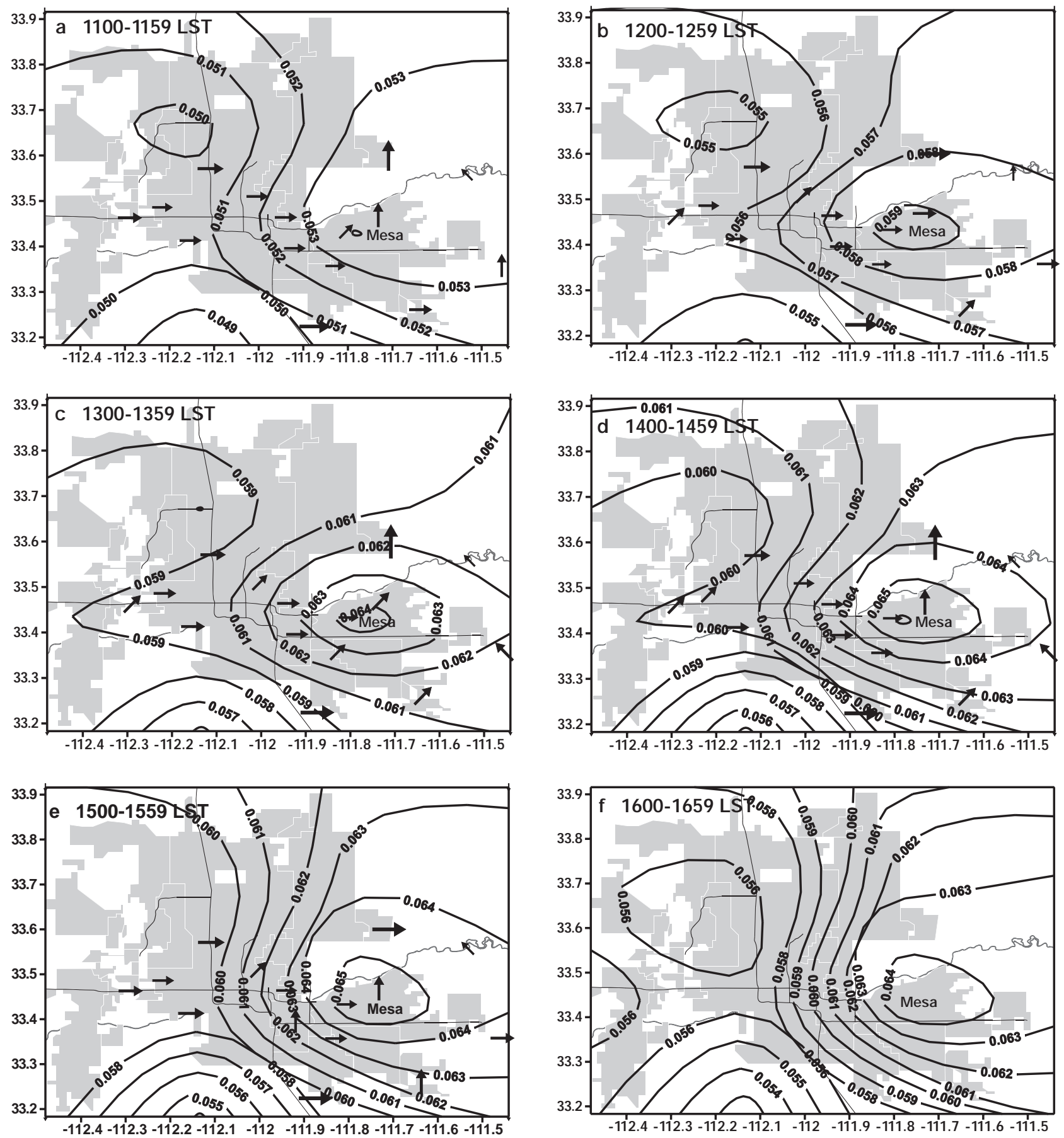

Fig. 9. Composites of ozone concentrations $(\mathrm{ppm})$ and predominant wind vectors $\left(0.25 \mathrm{~cm}=1 \mathrm{~m} \mathrm{~s}^{-1}\right)$ on days of moderate ozone

trations. On days of high ozone, an ozone plume that is transported by a light, but organized, lower atmospheric circulation could boost ozone concentration levels in the eastern metropolitan area beyond the high levels already produced by the large amounts of insola- tion on the very dry days. Such a circulation might be less organized on the more moist moderate ozone days, and unorganized on the relatively very moist days of low ozone, which also possessed wind speeds indicative of a stronger background synoptic circulation. 

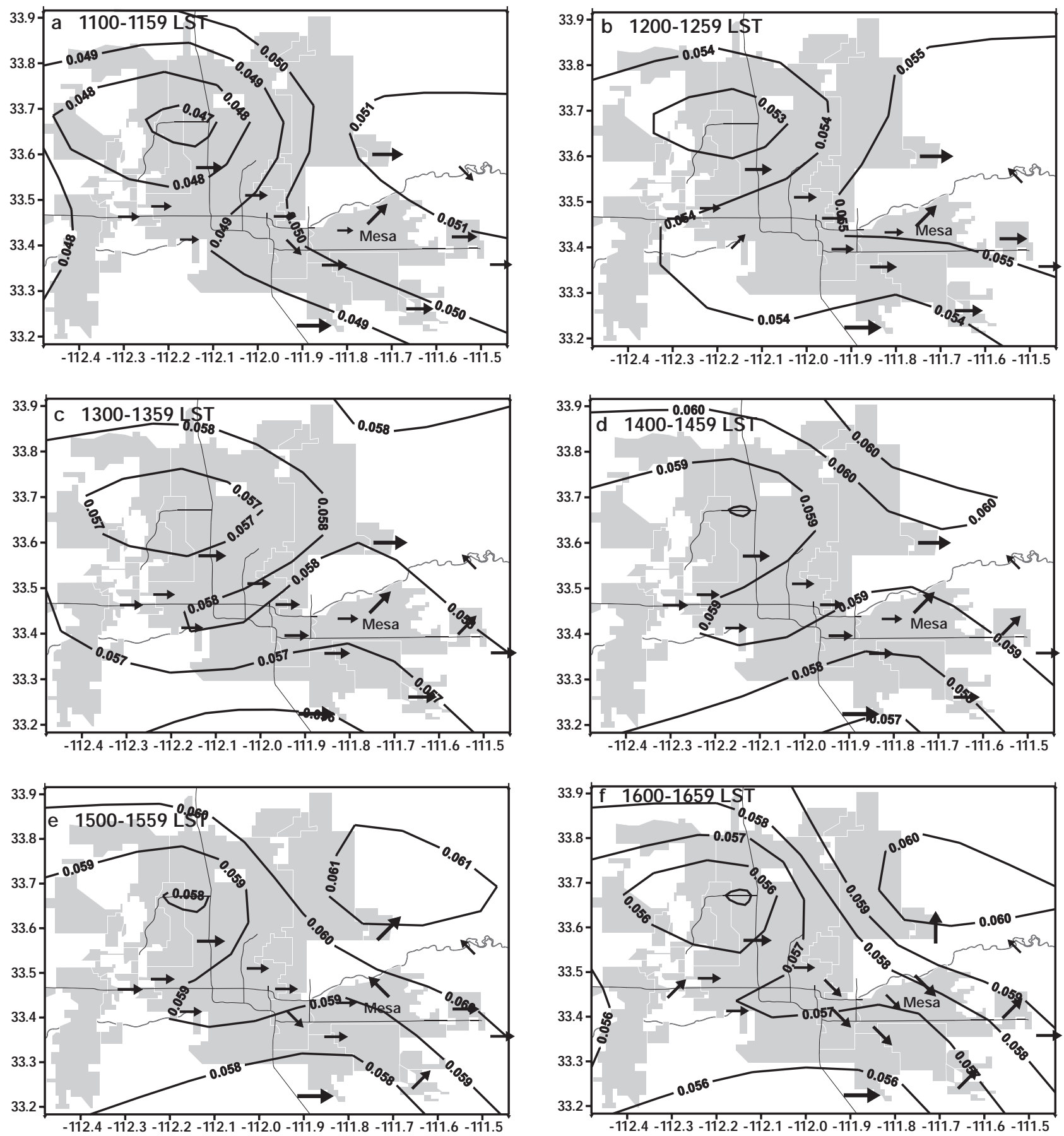

Fig. 10. Composites of ozone concentrations (ppm) and predominant wind vectors $\left(0.25 \mathrm{~cm}=1 \mathrm{~m} \mathrm{~s}^{-1}\right)$ on days of low ozone

\subsection{Background synoptic circulation}

Based on the micro- and mesoscale characteristics of the atmosphere associated with high, moderate, and low ozone days, it seems that the larger synoptic-scale atmospheric pattern may have been a contributor to lower atmospheric ozone concentrations in 2 ways.
First, the amount of atmospheric moisture advected into the region likely played an important role in the smaller-scale processes of ozone production (insolation) and the generation of a daytime upslope thermal circulation (insolation, surface and air temperatures). Second, the strength of the background synoptic circulation likely played a role in the degree to which lower 

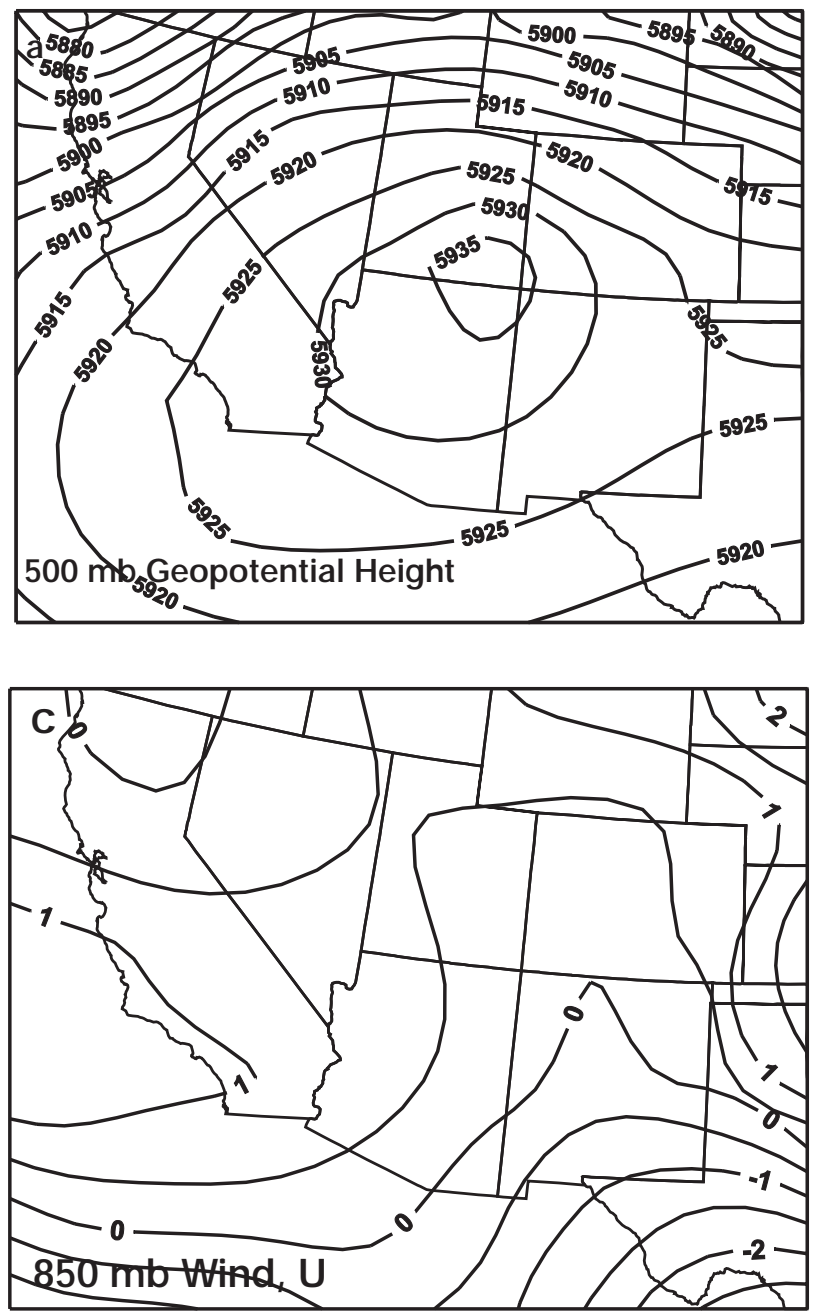
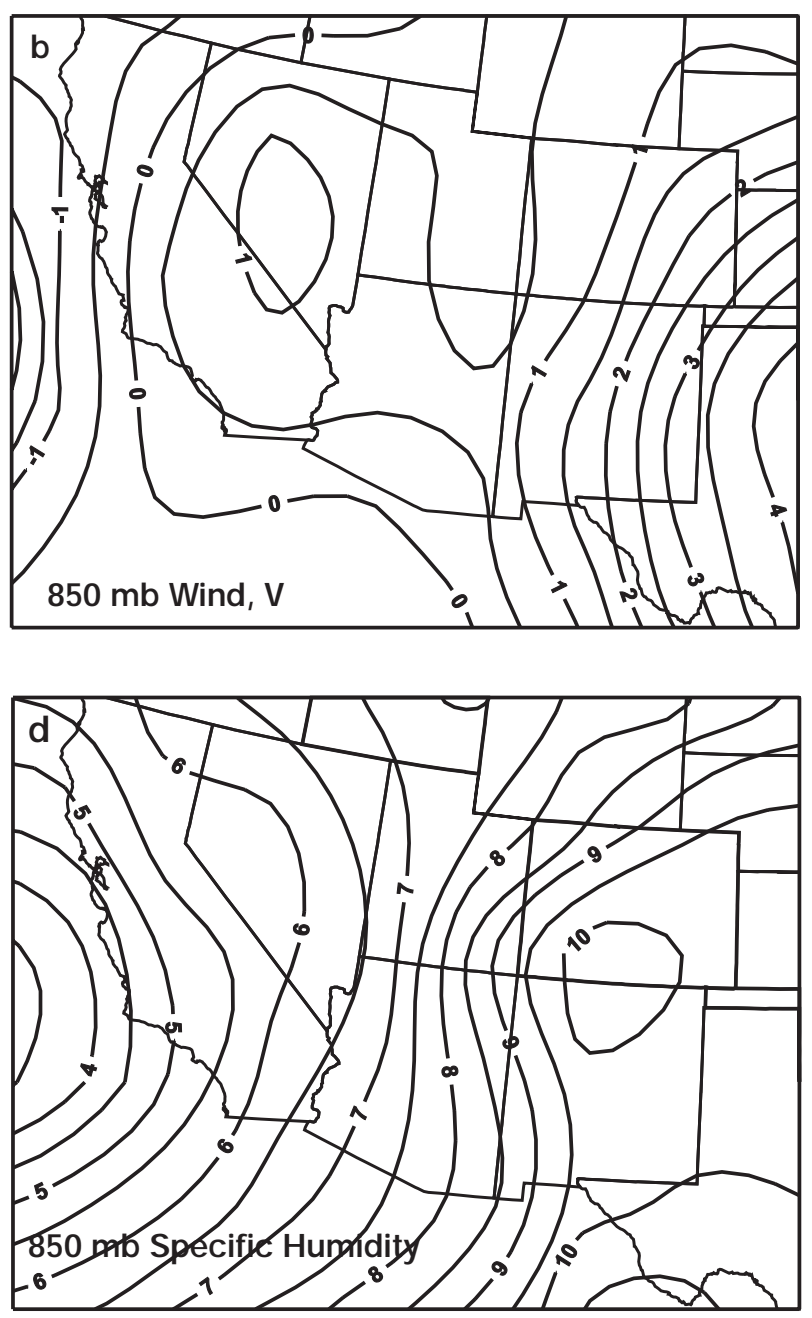

Fig. 11. Composites of (a) $500 \mathrm{mb}$ geopotential heights (gpm), (b) $\mathrm{V}$ and (c) $\mathrm{u}$ components of $850 \mathrm{mb}$ wind vectors (m s${ }^{-1}$ ), and (d) specific humidity $\left(\mathrm{g} \mathrm{kg}^{-1}\right)$ on days of high ozone

atmospheric ozone became mixed vertically, but it also likely influenced the organization of any mesoscale thermal circulation that was present.

The composite patterns of $500 \mathrm{mb}$ geopotential height for the high, moderate, and low ozone categories indicate the presence of a dome of high pressure aloft in each case. However, on average, the center of the dome or ridge of high pressure was located over western Arizona on high ozone days (Fig. 11a), over the Arizona-New Mexico border on moderate ozone days (Fig. 12a), and over southern Kansas and Oklahoma on low ozone days (Fig. 13a). The dome of high pressure aloft over Arizona on high ozone days likely produced subsidence, warming, and clear skies. This coincided with dry, warm, and calm conditions measured at the microclimate site, and a well-defined plume of lower atmospheric ozone moving eastward from the center of the urban area, whereas the low ozone days are typical of the monsoonal pattern.
The $u$ (+ west, - east) and v (+south, - north) components of the wind indicate subtle differences in the synoptic flow of the lower atmosphere on high, moderate, and low ozone days. On high ozone days, the $850 \mathrm{mb}$ flow over much of A rizona was light and from the southwest (Fig. 11b,c). Stronger westerly-southwesterly winds were located over California, while southerly and southeasterly winds were predominant in eastern New Mexico, southward into Mexico. The same pattern was evident on moderate ozone days (Fig. 12b,c), with $850 \mathrm{mb}$ winds over Arizona becoming slightly more southerly-southwesterly. On days of low ozone (Fig. 13b,c), winds over A rizona remained light, but southerly-southeasterly in direction, while winds west of Arizona were from the south. A cross $\mathrm{N}$ ew M exico, Texas, and Mexico, $850 \mathrm{mb}$ winds on low ozone days were stronger and from the southeast (Fig. 13b,c).

The flow of the atmosphere at $850 \mathrm{mb}$ appears to have directly influenced the transport of moisture into 

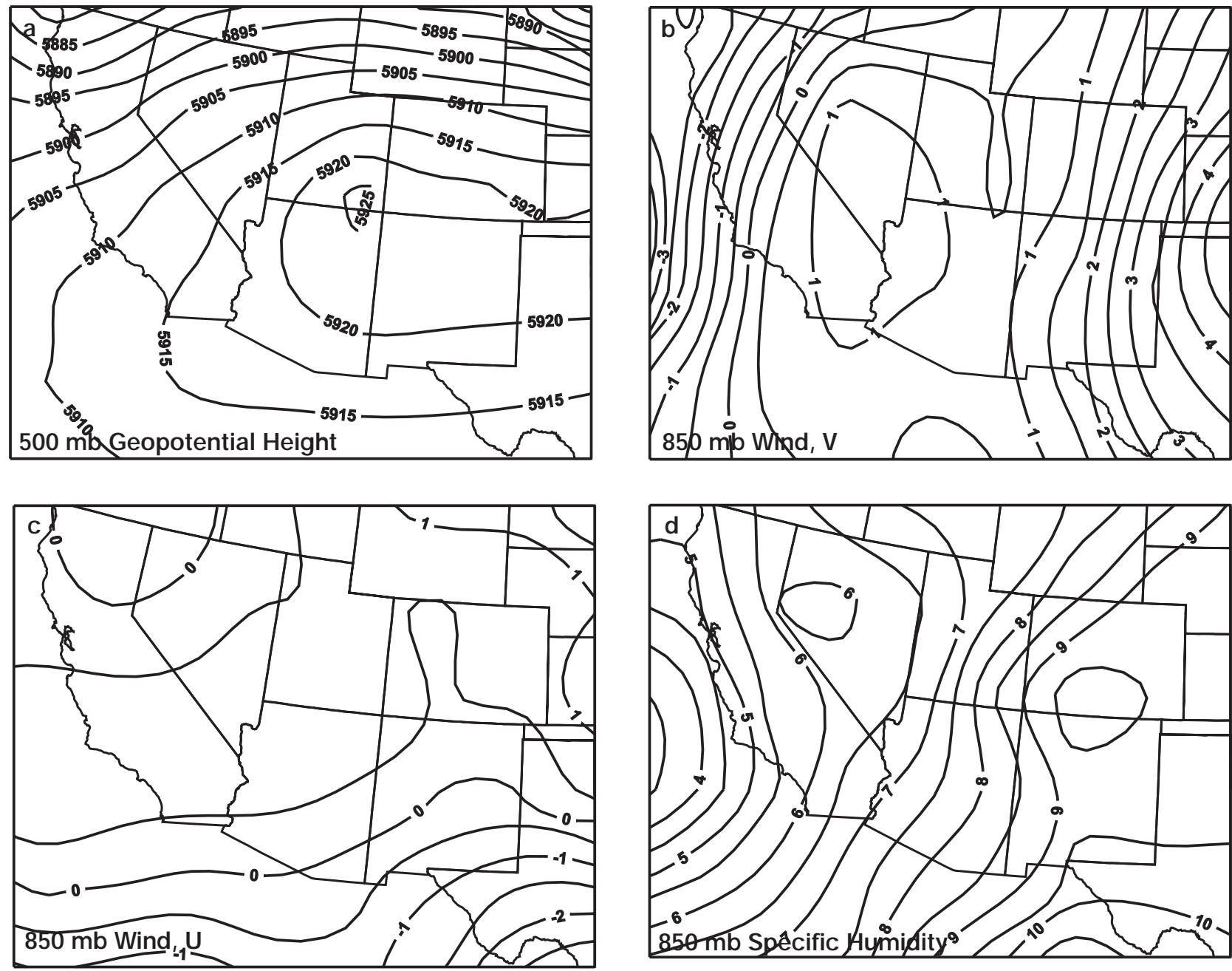

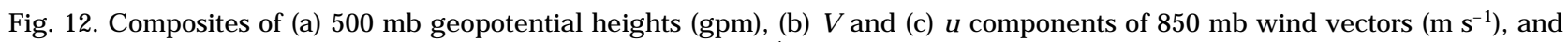
(d) specific humidity $\left(\mathrm{g} \mathrm{kg}^{-1}\right)$ on days of moderate ozone

A rizona on the study days. Composite maps of specific humidity indicate a northwestward progression of water vapor from days of high ozone to days of low ozone. On high ozone days, the average specific humidity in the Phoenix area was approximately 7 to $7.5 \mathrm{~g} \mathrm{~kg}^{-1}$ (Fig. 11d). On moderate ozone days, the average specific humidity increased slightly from the southeast to a value between 7 and $8 \mathrm{~g} \mathrm{~kg}^{-1}$ across south-central Arizona (Fig. 12d). Finally, on days of low ozone, the specific humidity increased from the southeast to a value of approximately $8.5 \mathrm{~g} \mathrm{~kg}^{-1}$ (Fig. 13d). The increase in moisture on days of moderate and low ozone concentrations likely was a reflection of the progressively eastward location of the dome of high pressure aloft, which was more conducive to the low-level transport of atmospheric moisture northwestward into A rizona (Carleton 1986). Without the presence of $500 \mathrm{mb}$ subsidence on moderate and low ozone days, greater mixing likely produced a less stratified boundary layer and a reduction in ozone levels.

\section{CONCLUSIONS}

Unhealthy levels of lower atmospheric ozone across the Phoenix urban area have been a focus of attention for the EPA and local government agencies over the past decade. Various studies of aerosol dispersion have focused on modeling the associated atmospheric circulation within a local airshed and statistically relating larger synoptic-scale circulation patterns to aerosol concentrations within urban areas. In recognizing the importance of the synergistic relationship between the condition of the atmosphere on the microscale, the mesoscale, and the synoptic scale, the case study presented here attempted to include a portion of all 3 

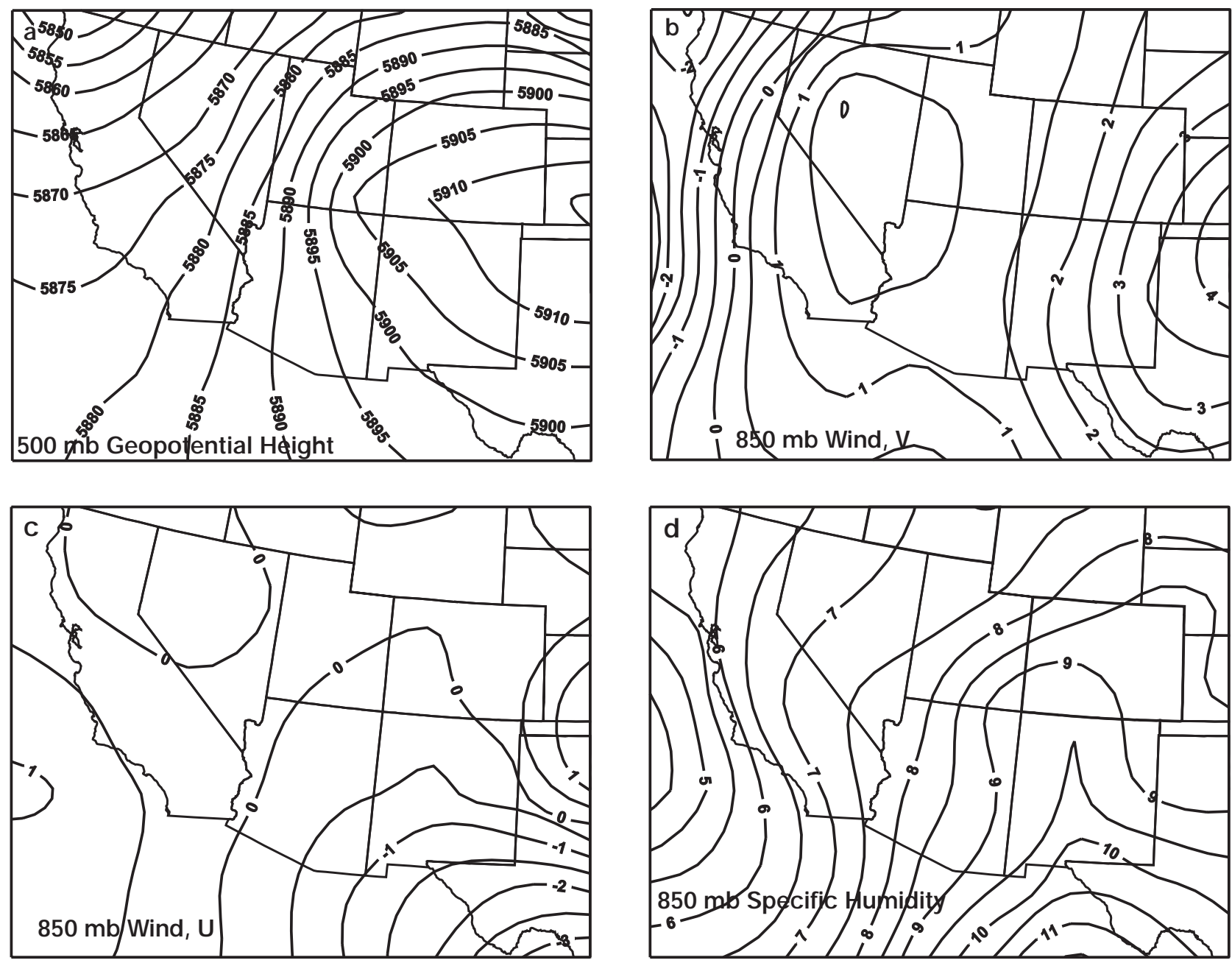

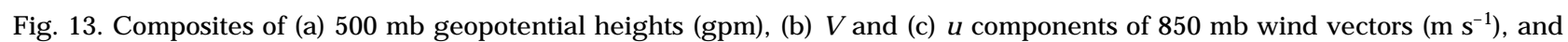
(d) specific humidity $\left(\mathrm{g} \mathrm{kg}^{-1}\right)$ on days of low ozone

scales in an analysis of the controls of lower atmospheric ozone transport across eastern Phoenix, Arizona, during summer 1998.

In stratifying the study days into the categories high ozone, moderate ozone, and low ozone, it was found that days of higher ozone amounts (exceeding EPA health standards) were typically drier (less atmospheric water vapor), allowing for a greater amount of insolation to reach the lower atmosphere. Moderate and low ozone days were associated with a moister lower atmosphere. The microclimate on high ozone days was associated with a dome of high pressure at $500 \mathrm{mb}$ located near the Phoenix area. The associated likelihood of dry air and warming through subsidence compliments the microclimatic data from high ozone days. Associated with the high pressure aloft were light low-level $(850 \mathrm{mb})$ winds from the southwest and relatively little advection of moisture at that level. On moderate and low ozone days, the area of high pressure aloft was farther east, and more so in the case of low ozone days. The result was a stronger flow at $850 \mathrm{mb}$ with a southeasterly component that advected moisture northwestward across central Arizona.

The fact that a drier atmosphere that allowed for a greater amount of insolation to reach the underlying surface was associated with high ozone concentrations is not surprising in that the production of ozone is a photochemical process. However, associated with the drier atmosphere and higher insolation on high ozone days were warmer ground surface and overlying air temperatures. Likely related to the location of the high pressure aloft were lower daytime wind speeds, and an atmosphere that appeared to be less mixed than those associated with moderate or low ozone concentrations. Given the weak background synoptic circulation and ample surface heating across the Phoenix Valley and 

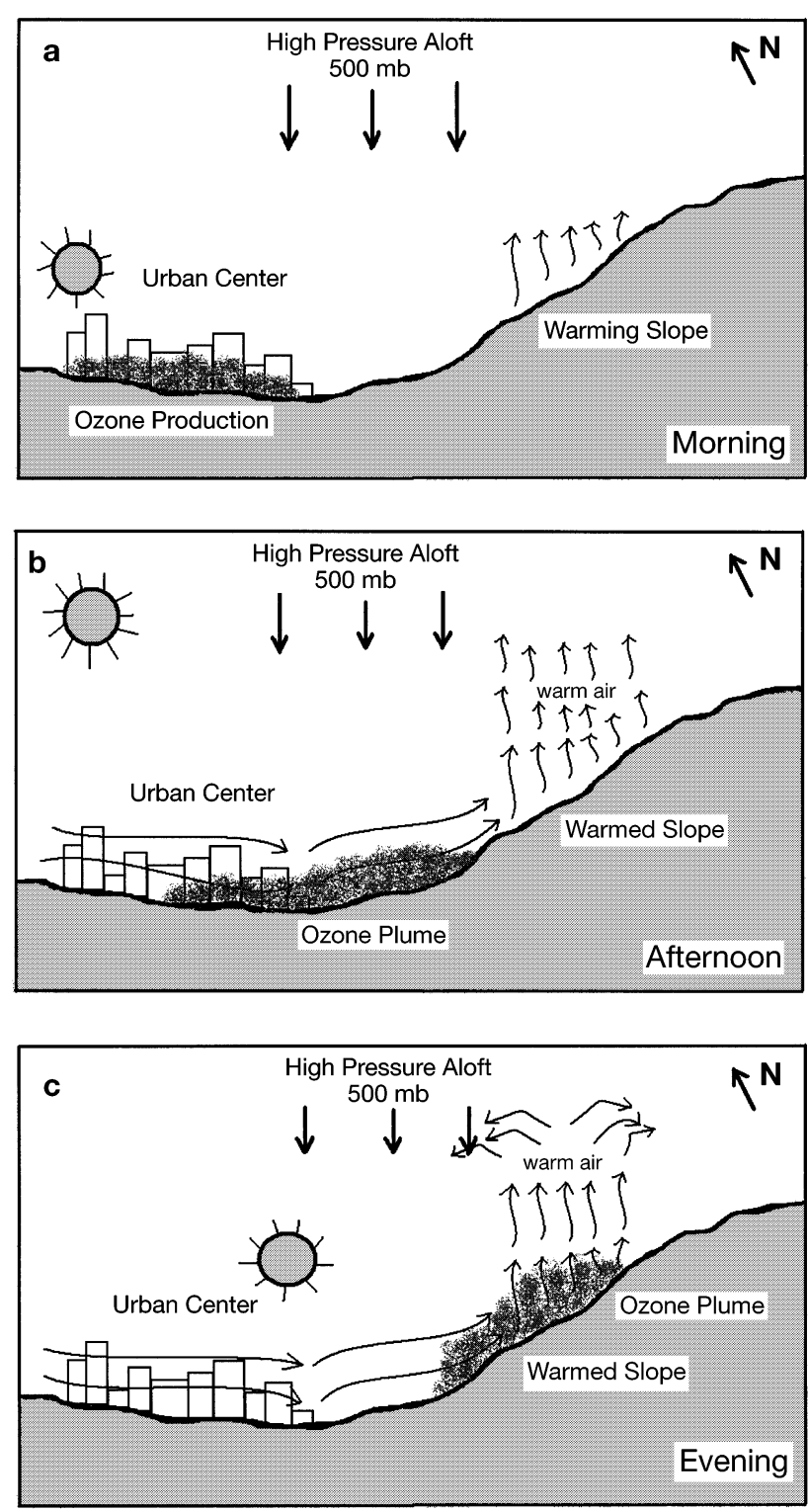

Fig. 14. A schematic of the transport of high concentrations of lower-atmospheric ozone across the Phoenix Valley as a product of the evolution of upslope flow through (a) morning,

(b) afternoon, and (c) evening hours

surrounding mountain slopes, it is reasonable to expect the development of a thermodynamic circulation oriented up the slopes of the higher terrain surrounding Phoenix, particularly toward the high elevations to the east. Microclimatic data associated with high ozone days indicated the diurnal evolution of such a wind regime, as did the predominant mesoscale wind patterns. Associated with an obvious west to east mesoscale flow on high ozone days was a concentrated plume of ozone that extended from a high ground traffic area eastward. The seemingly organized circulation was not associated with a distinct ozone plume on days of moderate ozone. Low ozone days showed little evidence of an organized spatial pattern of ozone concentration.

In summary, during mid-to-late summer 1998 across Phoenix, it appears the EPA standard for healthful ozone levels was exceeded in the suburb of Mesa on 11 days for 2 reasons. First, there likely existed a greater photochemical production of lower atmospheric ozone due to a greater amount of insolation passing through a dry atmosphere. Second, the lack of a strong background synoptic circulation likely reduced the lower atmospheric mixing of the gas, but it also did not hinder the apparent development of a mesoscale thermodynamic circulation that produced a distinct plume of ozone. The ozone plume extended eastward across Mesa from the urban center to the west, and likely increased the concentration of ozone over the eastern suburb of Phoenix. It is important to note that the process by which ozone was transported across the valley on high ozone days toward higher elevations to the northeast was a product of the synergistic relationship between the micro-, meso-, and synoptic-scale atmospheres (Fig. 14).

A longer recording period needs to be examined in order to better determine if the patterns characteristic of mid-to-late summer 1998 have general applicability. Interestingly, the typical succession of high, moderate, and low ozone days is logical synoptically speaking. This gives hope to the idea that there is indeed a sequence of atmospheric patterns that coincide with ozone concentrations across Phoenix, making high ozone days foreseeable.

Acknowledgements. The authors would like to thank the Arizona Department of Environmental Quality, specifically Peter Hyde, Fred Strasser, Steve Calderon, Gary Neuroth, Jerry Paoli, J im Guyton, Rose Spencer, and Sandra Wardwell for their help with instrumentation and data acquisition. For organizing the logistics, the authors would like to thank M ark Meyers, Manager of Falcon Field Regional Airport, Steven D'urso of the Federal Aviation Administration, and Eric Pardyjak and Mike Levy of the Environmental Fluid Dynamics Program of Arizona State University. Also appreciated are the helpful comments of 2 anonymous reviewers. This work was partially funded by National Science Foundation grant G708452 (Environmental Geochemistry and BioGeochemistry Initiative) and the Edna Bailey Sussman Trust.

\section{LITERATURE CITED}

Adams DK, Comrie AC (1997) The North American monsoon. Bull Am Meteorol Soc 78:2197-2213

Arnfield AJ (1982) An approach to the estimation of the surface radiative properties and radiation budgets of cities. Phys Geogr 3:97-122

Berman NS, Boyer DL, Brazel AJ, Brazel SW, Chen RR, Fernando HJS, Fitch MJ (1995) Synoptic classification and 
physical model experiments to guide field studies in complex terrain. J Appl Meteorol 34:719-730

Bryson RA, Lowry WP (1955) Synoptic climatology of the Arizona summer precipitation singularity. Bull Am Meteorol Soc 36:329-339

Carleton AM (1986) Synoptic-dynamic character of 'bursts' and 'breaks' in the southwest US summer precipitation. Ann Assoc Am Geogr 77:619-634

Comrie AC (1996) An all-season synoptic climatology of air pollution in the US-M exico border region. Prof Geogr 48: 237-251

Davis RE, Gay DA (1993) An assessment of air quality variations in the south-western USA using an upper air synoptic climatology. Int J Climatol 13:755-781

Davis RE, Kalkstein LS (1990) Development of an automated spatial synoptic climatological classification. Int J Climatol 10:769-794

Davis RE, Rogers RF (1992) A synoptic climatology of severe storms in Virginia. Prof Geogr 44:319-332

De Muer D (1997) Photochemical ozone production in the convective mixed layer. Studies with a tethered balloon sounding system. J Geophys Res 102:933-1015

Douglas MW, Li S (1996) Diurnal variation of the lower tropospheric flow over theA rizona low desert from SWAM P1993 observations. M on Weather Rev 124:1211-1224

Farfan LM, Zehnder JA (1994) Moving and stationary mesoscale convective systems over northwest monsoon Mexico during the southwest area monsoon project. Weather Forecast 9:630-639

Gammon RB, Huning J R, Reid MS, Smith J H (1981) Urban air pollution and solar energy. Int J Ambient Energy 2: 183-195

Gold DR, Damokosh AI, Pope CA, Dockery DW, McDonnell WF, Serrano P, Retama A, Castillejos M (1999) Particulate and ozone pollutant effects on the respiratory function of children in southwest M exico City. Epidemiology 10:8-16

Hales JE (1974) Southwestern United States summer monsoon source-Gulf of Mexico or Pacific Ocean? J Appl Meteorol 13:331-342

Editorial responsibility: Laurence Kalkstein, Newark, Delaware, USA
Harrington J A, Cerveny RS, Balling RC (1992) Impact of the southern oscillation on the North American southwest monsoon. Phys Geogr 13:318-330

Jurwitz LR (1953) Arizona's two-season rainfall pattern. Weatherwise 6:96-99

Kalkstein LS, Corrigan P (1986) A synoptic climatological approach for environmental analysis: assessment of sulfur dioxide concentrations. Ann Assoc Am Geogr 76:381- 395

Lacroix GC, Lambre C (1998) Ozone and immune system. Rev Malad Respir 15:699-711

Loibi W (1997) M odeling tropospheric ozone distribution considering the spatio-temporal dependencies within complex terrain. In: Kraak M M MJ , Fendel EM (eds) Advances in GIS research II. Taylor and Francis, London

Lu R, Turco RP (1995) Air pollutant transport in a coastal environment-II. Three-dimensional simulations over LoS Angeles Basin. Atmos Environ 29:1499-1518

McCollum DM, Maddox RA, Howard KW (1995) Case-study of a severe mesoscale convective system in central Arizona. Weather Forecast 10:643-665

McRae GJ , Goodin WR, Seinfeld N (1982) Formulation of an urban scale airshed model. In: McRae GJ, Goodin WR, Seinfeld J H (ed) M athematical modeling of photochemical air pollution. Environmental Quality Laboratory of the California Institute of Technology, Los Angeles, CA, p 13-62

Oke TR (1973) City size and the urban heat island. Atmos Environ 7:769-779

Rodwell MJ , Hoskins BJ (1996) Monsoons and the dynamics of deserts. Q J R M eteorol Soc 122:1385-1404

Rowson DR, Colucci SJ (1992) Synoptic climatology of thermal low-pressure systems over south-western North America. Int J Climatol 12:529-545

Sellers WD, Hill RH (1974) Arizona climate, 1931-1972. The University of Arizona Press, Tucson

US EPA (1998) Technical support document for the notice of final rulemaking on finding of failure to attain and denial of attainment extension for ozone in the Phoenix (A rizona) metropolitan area. US EPA, Washington, DC

Submitted: J une 1, 1999; Accepted: November 16, 1999 Proofs received from author(s): M arch 28, 2000 